University of the Pacific

Scholarly Commons

\title{
Raising the Bar: Law Schools and Legal Institutions Leading to Educate Undocumented Students
}

\author{
Raquel Aldana \\ Pacific McGeorge School of Law \\ Beth Lyon \\ Villanova University School of Law \\ Karla Mari McKanders \\ University of Tennesse College of Law
}

Follow this and additional works at: https://scholarlycommons.pacific.edu/facultyarticles

Part of the Immigration Law Commons

\section{Recommended Citation}

44 Ariz. St. L. J. 5 (2012)

This Article is brought to you for free and open access by the McGeorge School of Law Faculty Scholarship at Scholarly Commons. It has been accepted for inclusion in McGeorge School of Law Scholarly Articles by an authorized administrator of Scholarly Commons. For more information, please contact mgibney@pacific.edu. 


\section{ARIZONA STATE LAW JOURNAL}

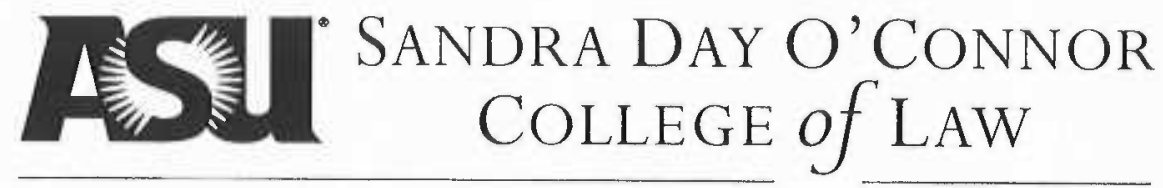

A R I ZON A S T A TE U N I VERSI T Y

RAISING THE BAR: LAW SCHOOLS AND LEGAL INSTITUTIONS

LEADing TO EdUCATE UndOCUMEnTED StUdentS

Raquel Aldana

Beth Lyon

Karla Mari McKanders 


\title{
RAISING THE BAR: Law Schools and Legal Institutions Leading to Educate Undocumented Students
}

\author{
Raquel Aldana* \\ Beth Lyon** \\ Karla Mari McKanders ${ }^{* * *}$
}

\section{INTRODUCTION}

This article is dedicated to aspiring lawyers like Luis Pérez, ${ }^{1}$ a recent graduate of the UCLA School of Law. Luis was smuggled across the border with his parents by a coyote when he was eight years old ${ }^{2}$ Like many other undocumented students in grade school, beginning days after his arrival from Mexico, Luis studied hard to master English and quickly displaced Spanish as his dominant language. ${ }^{3}$ As a teenager, Luis woke up every morning at 5:30 a.m. and took a long bus trip across the San Fernando Valley, to a safe high school where studying hard did not make him a target. ${ }^{4}$ When he eventually made it to college, it was the U.S. Constitution that piqued his scholarly interest, in particular the Bill of Rights. In 2010, his study of U.S. law and legal institutions culminated in his graduation

*. Professor of Law, University of the Pacific McGeorge School of Law.

**. Professor of Law, Villanova University School of Law.

***. Associate Professor of Law, University of Tennessee College of Law. While any errors are our own, we are incredibly grateful to a number of leading law academics and law school admissions directors who pushed and provided the courage and inspiration to write this paper, as well as insight into the complex issues facing undocumented law students and some of the best practices that they have adopted: Steve Bender; Keith Fogg; Dean Kevin Johnson; Cathy Miller-Wilson; Michael Olivas; Ediberto Roman; Leticia Saucedo; Dveera Segal; and Hazel Weiser. We also thank our excellent research assistants who did more than find sources of law; they sharpened our thinking about the issue, provided ideas, and improved our contributions: Gina Carrillo (Villanova Law 2013); Thomas Herman (Villanova Law 2011); Raissa Morris (Pacific McGeorge 2012); Katie Oldham (Pacific McGeorge 2011); Kimberly Rosenberger (Pacific McGeorge 2012); and Erika González (Pacific McGeorge 2012). We are also grateful to the participants in the Temple University Beasley School of Law February 29, 2012 faculty exchange for their comments and suggestions, and to the Arizona State Law Journal members Sasha Meschkow, Kyle Robertson, and Eric Wanner for their editorial work.

1. Hector Tobar, Undocumented UCLA Law Grad is in a Legal Bind, L.A. TIMES (Nov. 26, 2010), http://articles.latimes.com/2010/nov/26/local/la-me-tobar-20101126.
2. Id.
3. Id.
4. Id. 
from law school. ${ }^{5}$ Yet, Congress' failure to provide a coherent legal response to Luis has left him in a "legal bind." Luis sat for the California bar, but he still lives with the constant possibility of removal and with no prospect for authorized paid employment in the U.S., despite his successful completion of law school. Luis hopes that his status will change so he can pursue the life in law for which he has worked so hard. But employment opportunities for Luis will probably never, as he states, include anything more than the construction job in which he currently works (unauthorized) to pay off his law school debt. ${ }^{7}$ However, by allowing his story to be publicized, Luis and other undocumented aspiring lawyers are directly challenging the United States to face its unrealistic, unenforceable immigration regime.

Law schools are already both knowingly and unknowingly admitting and graduating undocumented ${ }^{8}$ students. ${ }^{9}$ Currently, this population is likely small. Our best estimate is that the number is likely around one hundred, attending roughly a dozen U.S. law schools. ${ }^{10} \mathrm{We}$ predict, however, that the number of undocumented law students entering law school will continue to grow. One estimate by the Urban Institute in 2003 put the number of

5. Id.

6. Id.

7. $I d$.

8. This paper will use the term "undocumented" to refer to individuals without legal permission to be admitted to or be present within the United States. For a discussion of terminology with respect to such persons, see Lozano v. City of Hazleton, 620 F.3d 170, 176 n.1 (3d Cir. 2010), vacated, 131 S. Ct. 2958 (2011) (citing Beth Lyon, When More 'Security' Equals Less Workplace Safety: Reconsidering U.S. Laws that Disadvantage Unauthorized Workers, 6 U. PA. J. LAB. \& EMP. L. 571, 576 (2004) ("Scholarly and popular concerns about the phrase 'illegal alien' abound, pointing out that the phrase is racially loaded, ambiguous, imprecise, and pejorative.")); see also Kevin R. Johnson, "Aliens" and the U.S. Immigration Laws: The Social and Legal Construction of Nonpersons, 28 U. OF MIAMI INTER-AM. L. REV. 263, 268 (1997).

9. Some schools are intentional and public in their approach to the admission, enrollment, and career support for undocumented students. See, e.g., Admission of Undocumented Students to Academic Study, CATHolic U. AM. (May 9, 2009), http://policies.cua.edu/enrollment/undocumented.cfm. The policy states that:

Since there are no laws at either the federal or the District level that bar the University from enrolling any sort of student, and in keeping with the social justice teachings of the Catholic Church, the University will not consider a student's immigration status in its decision to admit and enroll academically qualified students to its academic programs.

Id.

10. This estimate is based on interviews with legal academics and other individuals with close ties to undocumented law students. 
undocumented high school students graduating each year at $65,000 .{ }^{11}$ The Urban Institute also calculated that between 7,000 and 13,000 undocumented students enrolled in public colleges and universities in California alone that year. ${ }^{12}$ More recent studies reveal a similar trend nationally and in specific states. In 2009, the Pew Hispanic Center reported that of the undocumented individuals 18-24 who have completed high school in the United States, $49 \%$ are in college or have attended college. ${ }^{13}$ In Texas, "thousands" of undocumented students have enrolled in Texas undergraduate public colleges and universities under a provision of state law that permits such students to qualify for in-state tuition. ${ }^{14}$ Extrapolating from these figures, it is a short leap to estimate that the total number of undocumented college students now reaches the tens of thousands (some sources put it at 50,000). ${ }^{15}$ From this group, the number that apply to or attend graduate school in the United States is certainly smaller still, but as the undocumented population in the country increases, and greater numbers of undocumented college students graduate each year, that figure can be expected to grow. ${ }^{16}$ These students, moreover, reflecting immigration patterns and the racialized nature of U.S. immigration policy, ${ }^{17}$ are and will largely be Latino or other students of color, coinciding also with the need

11. Jeffrey S. Passel, Further Demographic Information Relating to the DREAM Act, URB. INST. (Oct. 21, 2003), http://www.nationalimmigrationreform.org/proposed/DREAM/Urban InstituteDREAM.pdf.

12. Id.

13. Jeffrey S. Passel \& D'Vera Cohn, A Portrait of Unauthorized Immigrants in the United States, PEW HISP. CTR. (Apr. 14, 2009), http://pewhispanic.org/reports/report.php? ReportID=107.

14. See Michael A. Olivas, Undocumented College Students, Taxation and Financial Aid: A Technical Note, 32 REV. OF HIGHER EDUC. 407, 408 (2009), available at http://lawprofessors.typepad.com/files/32-3-olivas-1.pdf.

15. Ilan Stavans, Academic Purgatory: An Illegal Immigrant Earns a Ph.D. Now What?, CHron. OF Higher EduC. (June 26, 2011), http://chronicle.com/article/AcademicPurgatory $/ 127970 \%$.

16. See, e.g., Yecenia Alfaro, Undocumented and Unafraid, AM. OBSERVER: AM. U. GRADUATE JOURNALISM MAG. (Apr. 4, 2011), http://inews6.americanobserver.net/content/ undocumented-and-unafraid (describing life of undocumented graduate student Gustavo Gutierrez at USC's School of Broadcast Journalism); Tobar, supra note 1; My Name is Michael and I Am Undocumented, CHANGE.ORG (May 8, 2009), http://news.change.org/stories/myname-is-michael-and-i-am-undocumented (documenting experience of undocumented individual in medical school); Tania Unzueta, Shifting the Paradigm of Undocumented Student Support, IMmigrant YouTH Just. League (Oct. 11, 2010), http://www.iyjl.org/?p=1606 (describing endorsement for DREAM Act by undocumented graduate student at University of Illinois at Chicago).

17. See generally Kevin R. Johnson, The "Huddled Masses" Myth: IMmigration and CIVIL RigHTS 9 (2004). 
for law schools to address the underrepresentation of people of color entering the legal profession. ${ }^{18}$

We are writing this paper because we believe that law schools, the American Bar Association, and the Association of American Law Schools can and should be in the forefront of developing and adopting best practices for the admission and graduation of undocumented students as lawyers and promoting their integration into the legal profession. We write this paper against the backdrop of the potential passage of Development, Relief and Education for Alien Minors ("DREAM") Act, which was reintroduced in Congress in $2011 .{ }^{19}$ The adoption of the DREAM Act, which would grant a path to legalization to the current and would-be law students who are the focus of this paper, would substantially resolve many of the complex factors that law schools must now consider, although not all. ${ }^{20}$ In the absence of DREAM Act legislation, this Article provides guidance to law schools and its accrediting agencies on the advisability, legality and best practices of graduating lawyers who are undocumented.

We acknowledge that there are tensions around the decision to educate undocumented law students. Law schools should worry about the appropriateness of graduating lawyers with high debt burdens and no prospects for paid employment inside the United States. These issues are not unique to undocumented law students. A recent New York Times story highlighted the terrible financial bind that increasing numbers of all recent law graduates face, owing to decreased prospects for gainful employment in the profession. ${ }^{21}$ Undocumented students, however, face unique challenges,

18. See, e.g., Presidential Initiative Comm'n ON Diversity, Am. Bar Ass'N, Diversity IN THE LEGAL PROFEsSION: THE NEXT STEPS 9-24 (2010), available at http://mldc.whs.mil/download/documents/Readings/Next\%20Steps\%20Final-Virtual\%20Access ible\%20042010.pdf.

19. See S. 3992, 111th Cong. (2010), available at http://thomas.loc.gov/cgibin/query/z?c111:S.3992:; Karoun Demirjian, Harry Reid Reintroduces the Dream Act: Action from Democrats Follows Obama's Call for Immigration Reform, LAS VEGAS SUN (May 11, 2011, 11:28 AM), http://www.lasvegassun.com/news/2011/may/11/harry-reid-reintroducesdream-act/.

20. The Dream Act, for example, would limit financial aid eligibility for these students to federal loans and work-study programs, which would improve but not entirely address the financial burdens endured by these students. See Chris Vogel, The DREAM Act Might Be Dead, But These Kids' Hopes Are Not, Hous. Press (June 18, 2008), http://www.houstonpress.com/2008-06-19/news/the-dream-act-might-be-dead-but-these-kidshopes-are-not/.

21. Editorial, Addressing the Justice Gap: The Poor Need Representation and Thousands of Law School Graduates Need Work, N.Y. TIMES, Aug. 24, 2011, at A22, available at http://www.nytimes.com/2011/08/24/opinion/addressing-the-justice-gap.html (reporting that with the economic downturn, only around two-thirds of law school graduates in 2010 got jobs 
including, for example, discerning in which states they may sit for the bar, or the fact that they cannot be remunerated for legal work performed in the U.S. Moreover, under current law, undocumented law students are not eligible for financial aid and student loans and are barred from employment in the U.S., ${ }^{22}$ which either makes legal education prohibitively expensive or economically unviable for most undocumented students. Still, there is no denying that law schools add value beyond the ability of students to earn a living practicing law; indeed, many students enroll in law schools without ever wanting to practice law. For undocumented students in particular, the study of law could empower them through the exploration of power and social dynamics that have shaped U.S. immigration policies and that explain their current plight. Law schools, moreover, could also help form and channel these students' passions, creativity, and commitment as activists to seek legal reform to improve not only their own plight but that of others. These students could also capitalize on their law degrees to subsequently seek authorized employment whether in the U.S., in other countries or with international legal institutions. ${ }^{23}$ We maintain, therefore, that law schools, the ABA, and the AALS can lead in creating solutions to the unique challenges facing undocumented students. Our aim in this paper is to start a dialogue on best practices that could also improve the plight of recent undocumented law graduates, including their prospects for meaningful engagement as lawyers within and outside of the United States.

It is our contention, after careful analysis, that no law precludes law schools from admitting undocumented students, offering them in-state tuition or other types of private and even public financial aid in states that permit it, or allowing them to participate fully in the law schools' educational opportunities. ${ }^{24}$ Law schools should not be in the business of enforcing U.S. immigration laws or any other laws which they are not required to enforce. Unlike employers, institutions of higher learning are not required to maintain students' immigration records, except for documented non-resident foreign students and for financial aid eligibility

for which a law degree is required, the lowest rate since 1996, leaving 15,000 without legal jobs).

22. See infra Part II.A.

23. An undocumented student's unlawful stay in the U.S. under current immigration law would most likely represent a 10-year bar to legalization. 28 U.S.C. $\S 1182$ (a)(9)(B) (2006). However, the preference for highly-skilled work visas under U.S. immigration policies still improves considerably the chances that students with law degrees could seek subsequent employment-based immigration in the U.S. It could also improve their chances of legalization under any potential comprehensive immigration law that provides a path of legalization to existing undocumented persons.

24. See infra Part II. 
purposes. ${ }^{25}$ Furthermore, Congress has explicitly reserved to states determinations of who is a resident for purposes of admission and tuition; ${ }^{26}$ thus, students who otherwise meet the state definition of residency should not be required to disclose their immigration status. Moreover, immigration legal status is irrelevant to the successful completion of legal studies. Nothing precludes law schools from allowing all law students to participate in externships or clinical programs, for example, as these are not for pay, and thus are not considered employment. ${ }^{27}$

For some, the admission and graduation of undocumented law students may also raise other types of resource allocation and moral dilemmas in terms of, for example, whether their admission takes away from limited resources for other students who should have priority, namely disadvantaged U.S. citizens or lawful permanent residents. State schools, for example, are required or pressured by state legislatures to give preference to in-state resident students over out-of-state students in the admission decisions, principally in response to the argument that the state's duty is mostly to its own residents; or simply the hope that resident lawyers will likely contribute more greatly to the state. Relatedly, even if legally permissible, some might argue that law schools and legal institutions, especially, should uphold the rule of law and not reward illegality by promoting "illegal lawyers." We reject these arguments as based on faulty economic assumptions about the availability of subsidized higher education for undocumented students and for their own moral deficiency.

First, the education of undocumented students admitted into law schools is not substantially subsidized through public money, simply because undocumented students are already ineligible for financial aid and student loans. ${ }^{28}$ The only type of partial public subsidy that some undocumented law students could receive would be based on their eligibility to pay in-state tuition or access to private and public scholarships in the few states that grant benefits to undocumented students, usually based on at least three years of high school study and graduation in that state. ${ }^{29}$ Thus, the claim of unfair allocation of public monies to educate undocumented students is only likely to be made by non-resident U.S. citizen and lawful permanent resident students who complain about having to pay out-of-state tuition in public universities in the few states that permit undocumented students to

25. See infra notes 194-204 and accompanying text.

26. See infra Part III.A.2.

27. See infra Part IV.

28. See infra Part III.A.2.

29. See infra Part III.A.2. 
pay in-state tuition. ${ }^{30}$ These non-resident U.S. citizen or lawful permanent resident students, however, are already granted in-state tuition in the states in which they are residents; their claim is simply to be treated as residents in states in which they have not lived simply because a few undocumented students who have lived in that state for years and who have graduated from those states' high schools are paying in-state tuition.

Second, the construction of morality through the simple lens of legality in this context ignores a much more nuanced understanding of why these undocumented students are in their current plight. The attribution of perpetual blame on these youths for the illegal border crossing or visa overstays of their parents has enormous human and societal consequences. For the undocumented student who came as a baby or child to the United States and who has been raised exclusively in this society, his or her belonging in U.S. society is indistinguishable, and perhaps even more profound than that of a recently arrived legal resident or even a U.S. citizen who has spent part or most of his life living abroad. The lives of these youths were not frozen at the border; they have built deep cultural and social roots in the United States that we cannot simply ignore today. These youths became members of this society, and a visa overstay or illegal border crossing in their remote past cannot undo that.

Luis's plight is at the root of the moral decay of a bounded construction of membership. Is Luis less of a member of U.S. society because of a border? Should his parent's past illegal crossing deny Luis the possibility of a better life? In its 1982 decision in Plyler v. Doe, the U.S. Supreme Court held that $\mathrm{K}-12$ grade school undocumented children are entitled to free public education. ${ }^{31}$ The Court reasoned that undocumented children should not be held accountable for their parents' actions. The Court also worried about creating a perpetual class of second-class citizens, who would inevitably be mostly Brown; accordingly, the Court found that the State of Texas did not have a compelling state interest in denying undocumented children a grade school education. ${ }^{32}$ Plyler, however, failed to resolve the fate of these children beyond high school graduation, who find themselves unable to legally work and, in most cases, unable to attend college. Moreover, the political reality of the Court today makes it also unlikely that

30. See, e.g., Martinez v. Regents of the Univ. of Cal., 241 P.3d 855, 860 (Cal. 2010) (challenge brought by U.S. citizens paying nonresident tuition at state colleges and university against California state statute exempting certain nonresidents including undocumented immigrants from paying nonresident tuition).

31. Plyler v. Doe, 457 U.S. 202, 230 (1982).

32. Id. 
the morally compelling arguments that created a legal right in 1982 will carry the day today. ${ }^{33}$

Hence, the goal of this project to encourage law schools, the ABA, and the AALS, to engage in the thoughtful examination of admission, retention, graduation, and incorporation of lawyers who are undocumented. To support institutions, including the Law School Admissions Council, which are beginning to publicly engage this topic, the paper includes a first attempt at a best practices guide for law schools admitting undocumented students. The piece aims to be precise and nuanced about the legal, practical, and moral challenges to some extent that law schools face in enrolling undocumented students. The paper will focus on three main areas. First, the paper will examine the American Bar Association ("ABA") 20112012 Standards and Rules of Procedure for Approval of Law Schools (the "Standards") and American Association of Law Schools. These standards set forth the minimum requirements developed to provide a sound program of legal education. ${ }^{34}$ The paper also considers state rules on bar admission and examines impediments in some states to sitting for the bar examination. ${ }^{35}$ Second, the paper outlines current laws governing financial aid for undocumented students and their eligibility to participate in educational experiential opportunities while in law school. ${ }^{36}$ This section also puts to rest the misperception that an educational institution may be held liable under the Immigration and Nationality Act's harboring provisions for admitting undocumented student. ${ }^{37}$ Finally, the paper outlines best practices for guiding undocumented law students from admission through beginning their legal career. ${ }^{38}$

II.

THE REGULATION ON THE ADMISSION OF UNDOCUMENTED LAWYERS INTO THE PROFESSION

\section{A. The ABA and AALS Rules Governing Undocumented Students}

The ABA and the AALS establish rules that govern the accreditation and standards under which U.S. law schools must operate. Thus, this section of

33. See Mary Carol Combs, Norma González \& Nina Rabin, Understanding Plyer's Legacy: Voices from Border Schools, 37 J.L. \& EDUC. 15, 15 (2008).

34. We conclude that the ABA rules do not hinder law schools from admitting undocumented law students. See infra Part II.A.

35. See infra Part II.B.

36. See generally infra Part III.

37. See infra Part III.A.

38. See infra Part IV. 
the paper examines any American Bar Association and American Association of Law Schools Rules with which law schools must comply in the admission, retention and graduation for undocumented law students. Further, these rules are explained in the context of relevant immigration law and state bar admission rules that law schools must consider.

Currently, ABA and AALS rules do not directly regulate the treatment of undocumented students by U.S. law schools. There are, however, some general rules that law schools should consider in their decision to educate undocumented students. Specifically, ABA Standard 501(b) provides that "law school shall not admit applicants who do not appear capable of satisfactorily completing its educational program and being admitted to the bar." ${ }^{.39}$ The most relevant portion of this rule as it relates to undocumented law students is their ability to be admitted to the bar given that their unauthorized stay in the United States could prevent them from admission to the bar in at least two ways: Are undocumented students even eligible to sit for the bar? Even if they are, are they barred from being admitted into the practice of law based on the effect on character and fitness of their unauthorized entry or stay in the United States and related conduct.

ABA Standard 501(b), however, may not even require admission into any state's bar. ABA Standard 501(b) could be given a narrower construction not a literal one: these students need not have a legal ability to sit for and be admitted to the bar, but merely the academic potential to pass the bar, were they to choose to sit for the exam upon graduation. In practice, in fact, this is primarily how this rule affects law schools since it is hardly ever the case that law students are legally ineligible to be admitted to the bar. Thus, law schools generally focus on an assessment of the academic capability of students passing the bar by considering, for example, the predictive value of law school entrance exam scores and grade point average; in turn, the ABA regulates compliance with ABA Standard 501(b) by imposing certain bar passage benchmarks for each law school. ${ }^{40}$ Indeed, this narrower interpretation makes sense considering that as a general matter law schools have no direct control over bar admission rules, and the ABA and the AALS are really attempting to govern best practices with regard to the fairness of the admissions process and the quality of legal education. The closest parallel to this issue is when law students who may have

39. Section of Legal Educ. And Admissions to the Bar, Am. BAR Ass'n, ABA StANDARDS AND RULES OF PROCEDURE FOR APPROVAL OF LAW SCHOOLS 37 (2011-12), available at http://www.americanbar.org/content/dam/aba/publications/misc/legal_education/ Standards/2011_2012_standards_and_rules_for_web.authcheckdam.pdf [hereinafter ABA STANDARDS].

40. Id. 
committed crimes prior to their admission into law schools could be barred based on character and fitness to be admitted into the practice of law. This issue has confronted law schools from time to time. ${ }^{41}$ In at least a few prominent examples, law schools have taken the defensible position that those persons seeking admission into U.S. law schools should be given an opportunity to graduate from a U.S. law school and to challenge their legal exclusion from being admitted to the bar before the relevant legal institutions in charge of those decisions. ${ }^{42}$ In their view, ABA Standard 501(b) should not require law schools to do more than make a best effort to evaluate students' academic potential to pass the bar. It is not a law school's competence or jurisdiction to decide whether undocumented students should be able to practice law and, moreover, denying their admission actually denies them the ability to challenge their exclusion from the practice of law. Regardless of the merit of this position, in this paper, we do explore the implications of undocumented law graduates to take the bar and be admitted as lawyers.

Further, law schools must also comply with the non-discriminatory provisions of the $\mathrm{ABA}$ rules that provide for equal opportunities for admission into law schools. ${ }^{43}$ The ABA rules provide that law schools' admissions policies shall be consistent with the diversity and nondiscrimination provisions of the rules. ${ }^{44}$ AALS also has similar non-

41. See Rebecca Leung, The State vs. James Hamm, CBS News (Feb. 11, 2009, 7:49 PM), http://www.cbsnews.com/stories/2004/10/13/60II/main649084.shtml.

42. Id.

43. Standard 211. Non-Discrimination and Equality of Opportunity (a) A law school shall foster and maintain equality of opportunity in legal education, including employment of faculty and staff, without discrimination or segregation on the basis of race, color, religion, national origin, gender, sexual orientation, age or disability. (b) A law school shall not use admission policies or take other action to preclude admission of applicants or retention of students on the basis of race, color, religion, national origin, gender, sexual orientation, age or disability.

ABA STANDARDS, supra note 39, at 15.

Standard 212. Equal Opportunity and Diversity (a) Consistent with sound legal education policy and the Standards, a law school shall demonstrate by concrete action a commitment to providing full opportunities for the study of law and entry into the profession by members of underrepresented groups, particularly racial and ethnic minorities, and a commitment to having a student body that is diverse with respect to gender, race, and ethnicity.

Id. at 16 .

44. "Interpretation 501-2: A law school's admission policies shall be consistent with Standards 211 and 212." Id. at 37.

Interpretation 501-3: Among the factors to consider in assessing compliance with Standard 501(b) are the academic and admission test credentials of the law school's entering students, the academic attrition rate of the law school's 
discriminatory provisions that encourage law schools to seek to increase enrollment of underrepresented groups in law school. ${ }^{45}$ This would invariably include undocumented law students who traditionally would not have access to legal education. There is a certain quality of diversity that undocumented law students bring to the law schools along with other underrepresented groups. Thus, this section of the paper also draws the connection between the admission of undocumented students and the diversification of law students and the legal profession.

\section{B. Immigrants' Eligibility to be Admitted into the Practice of Law}

Currently, at least three recent law graduates who are undocumented in three states - California, Florida, and New York, are reported to be awaiting results on whether, despite their successful completion of law school and the bar examination, they will be admitted into the state bar in their

Id.

students, the bar passage rate of its graduates, and the effectiveness of the law school's academic support program.

45. Article 6. Requirements of Membership, Section 6-1 Core Values (b)(v) "selection of students based upon intellectual ability and personal potential for success in the study and practice of law, through a fair and non-discriminatory process designed to produce a diverse student body and a broadly representative legal profession." ASS'N OF AM. LAW SCH., AALS HANDBOOK: BYLAWS (2008), http://www.aals.org/about_handbook_bylaws.php. In the AALS, Statement on Diversity, Equal Opportunity and Affirmative action section of 'Statements of Good Practices' it says:

[The purpose of AALS] seeks to increase the number of persons from underrepresented groups in law schools, in the legal profession and in the judiciary in order to enhance the perception of fairness in the legal system, to secure legal services to all sectors of society, and to provide role models for young people.

Ass'N OF AM. LAW SCH., AALS HANDBook: Statements of Good Practices (2008), http://www.aals.org/about_handbook_sgp_div.php. Further, it says:

Its objective is also to create an educational community-and ultimately a profession-that incorporates the different perspectives necessary to a more comprehensive understanding of the law and its impact on society; and to assure vigorous intellectual interchanges essential for professional development. It also implies changing the culture of educational institutions-making learning, the curriculum, and pedagogy more responsive to the needs of a changing student population and a changing world. It presumes an obligation to create a greater sense of belonging, of connectedness, and of place for all members of the educational community. In an increasingly multicultural nation with a global reach, a commitment to diversity - to broadening the boundaries of inclusiveness of American institutions-is economically necessary, morally imperative, and constitutionally legitimate. 
respective states. ${ }^{46}$ The admission of immigrants to the bar is not an entirely new issue. In 1973, in In re Griffiths, the U.S. Supreme Court addressed whether a lawful permanent resident, ${ }^{47}$ was eligible to sit for the Connecticut bar exam. ${ }^{48}$ Connecticut law conditioned bar admission on United States citizenship and excluded "[all] aliens from the practice of law." 49 The Supreme Court struck down Connecticut's law for adopting a suspect classification by preventing lawful permanent residents from practicing law in the state without a compelling state interest. ${ }^{50}$ In another case, LeClerc v. Webb, the Fifth Circuit addressed whether Louisiana's bar admission rule barring nonimmigrants ${ }^{51}$ from sitting for the bar was constitutional..$^{52}$ The Louisiana bar rule required that "[e]very applicant for admission to the Bar of this state shall . . . [b]e a citizen of the United States or a resident alien thereof." ${ }^{\text {" }} 33$ Resident "alien" was defined as an immigrant who is lawfully within the country. ${ }^{54}$ The plaintiffs in the case were graduates from foreign law schools who wanted to sit for the Louisiana bar. ${ }^{55}$ The plaintiffs contended that the Louisiana bar rule violated their rights under the Equal Protection Clause of the Fourteenth Amendment, the Due Process Clause of the Fifth Amendment, and the Supremacy Clause. ${ }^{56}$ The court stated that "[c]ontrary to the plaintiffs' contention, nonimmigrant aliens - who ordinarily stipulate before entry to this country that they have no intention of abandoning their native citizenship, and who enter with no enforceable claim to establishing permanent residence or ties here-need not be accorded the extraordinary protection of strict scrutiny by virtue of

46. Martha Neil, CUNY Law Grad Reveals Undocumented Status, Fears He Can't Practice Despite Passing the Bar, ABA J. (Mar. 7, 2012, 9:33 AM), http://www.abajournal.com/news/article/cuny_law_grad_reveals_undocumented_status_fears_h e_cant practice_despite_pa.

47. A permanent resident alien is an immigrant who comes to the United States and intends to live in the United States permanently. See generally, STEPHEN H. LEGOMSKY, IMMIGRATION AND REFUGEE LAW AND POLICY 9 (4th ed. 2005) (distinguishing between immigrants and non-immigrants, noting that the term immigrants includes both those who have been lawfully admitted as immigrants ("permanent resident aliens" or "lawful permanent residents") and those who have not as "undocumented immigrants").

48. In re Griffiths, 413 U. S. 717, 719 (1973).

49. Id.

50. Id.

51. LEGOMSKY, supra note 47, at 9 ("The Immigration and Nationality Act defines nonimmigrants as those who fall within any of several specifically enumerated categories of (typically) temporary entrants. Common examples are tourist, business visitors, students and temporary workers, but there are many others as well.").

52. LeClerc v. Webb, 419 F.3d 405 (5th Cir. 2005).

53. Id. at 410 .

54. Id.

55. Id.at 411 .

56. Id.at 414 . 
their alien status alone. ${ }^{957}$ The Fifth Circuit, thus, held that nonimmigrant classification would only be subject to rational basis review. ${ }^{58}$ The Fifth Circuit further agreed that Louisiana had a

substantial interest in regulating the practice of those it admits to its bar. Section 3(B) aims to assure clients that attorneys licensed by the Louisiana Bar will provide continuity and accountability in legal representation. The Bar's ability to monitor, regulate, and, when necessary, discipline and sanction members of the Bar requires that it be able to locate lawyers under its jurisdiction. The State's determination that the easily terminable status of nonimmigrant aliens would impair these interests and their enforcement capacity is not irrational. ${ }^{59}$

Under the Supremacy Clause, plaintiffs argued that the "comprehensive statutory scheme embodied in the Immigration and Nationality Act ("INA")" conflicted with the Louisiana bar rule. ${ }^{60}$ The court did not apply a presumption against preemption but rather indicated that the Louisiana bar rule was unquestionably a permissible exercise of Louisiana's broad police powers to regulate employment within its jurisdiction for the protection of its residents. ${ }^{61}$ The State alleged that the bar rule was designed to address local problems arising from the transitory status of nonimmigrant aliens who, by the terms and conditions of their federal status, possess fewer ties to the United States than any other group (besides illegal aliens). Section 3(B) attempts to protect Louisiana residents seeking legal representation and affects a class of persons whom Congress has expressly prohibited from living or working permanently in the United States. Rather than standing as an obstacle, the Fifth Circuit considered the Louisiana law as a promotion of federal immigration policy. ${ }^{62}$

These two cases combined leave undocumented law students seeking admission into the bar largely unprotected by the U.S. constitution. ${ }^{63}$ Thus, whether an undocumented student who has graduated from a U.S. law school may sit for the bar is largely dependent on the state law or practice. In general, while it is true that many states either explicitly preclude undocumented students to sit for the bar through statute or through bar admission practices, not all of them do.

\footnotetext{
57. Id. at 417 .

58. $I d$. at 420 .

59. Id. at 421 .

60. Id. at 423 .

61. Id.

62. Id. at 426 .

63. To date, no equal protection challenge to a state preclusion to the bar has been attempted under a state's constitution.
} 
It is crucial to clarify, moreover, that contrary to recent reports in the media, federal law does not regulate the issuance of professional licenses by states, including a license to practice law. A July 2011 story about a California State Bar panel which is considering whether to admit as a member of the bar Sergio García, an undocumented law graduate who successfully passed the bar in 2009, has not only provoked controversy around the morality of such a request but confusion around whether federal law would govern this issue. ${ }^{64}$ One story misstated federal law when it reported that the 1996 Personal Responsibility and Work Opportunity Act made "illegal immigrants...ineligible for a professional license issued by a state or local government agency." 65 This is simply not the case. The actual text of the legislation, which proscribes the provision of "federal public benefits," defines the term as "any grant, contract, loan professional license, or commercial license provided by an agency of the United States or by appropriated funds of the United States." ${ }^{16}$ Unless the California State Bar operates with appropriated funds of the United States, this provision is inapplicable. Of course, it is true that federal immigration law prohibits employers from hiring undocumented workers, ${ }^{67}$ but admission into the California Bar would not in any way grant Sergio García any authority to work in the United States, or in California, contrary to federal law. Sergio García still has to contend with those federal immigration law work restrictions and his unlawful stay in the country remains unchanged with the conferral of the license; that is, Mr. García is subject to removal whether or not he has a license to practice law. On the other hand, as we explain below, what could weigh into the admission decision taken by the California State Bar is Mr. García's conduct, including how any of his breaches of law could bear on an assessment of his character and fitness to practice law.

\section{State Bar Rules that Impact Undocumented Law Graduates' Admission to the Bar}

When examining state bar admission rules, there are three requirements that impede undocumented law graduates from being admitted to the Bar:

64. Scott Herhold, Why We Should Find a Way for Sergio C. Garcia to Practice Law, MERCURY NEWS (July 15, 2011), http://lesliebrodie.posterous.com/herhold-why-we-shouldfind-a-way-for-sergio-c (posted on Lesliebrodie's Posterous Blog).

65. See, e.g., id.; Don J. DeBenedictis, Bar May Deny Membership to Undocumented Lawyer, DAILY J. NeWSWIRE (July 6, 2011).

66. Personal Responsibility and Work Opportunity Reconciliation Act, H.R. 3734, 104th Cong. $\S 401(c)$ (1996), available at http://thomas.loc.gov/cgi-bin/query/z?c104:H.R.3734.ENR: (emphasis added).

67. 8 U.S.C. $\S 1324(2006)$. 
requests for immigration status and/or social security numbers; requirements to pass character and fitness tests; and background checks. ${ }^{68}$

\section{a. Requests for Immigration Status or Social Security Numbers}

Several states ask varying questions regarding immigration status. ${ }^{69}$ In some states, including Arizona, Arkansas, Colorado, Connecticut, Florida, Georgia, Kentucky, New Mexico and Louisiana, the question appears to act as an automatic bar to admission to those who are not at least nonimmigrants authorized to work in the United States. ${ }^{70}$ In Texas, for example, while state legislation ${ }^{71}$ proscribes denial of bar admission based on a person's immigration status; State Bar rules restrict eligibility to those who possess at a minimum authorization to work as nonimmigrants in the U.S. ${ }^{72}$ The hurdle for undocumented applicants based on immigration status inquiries in bar exam applications is even more evident for states that explicitly require proof or documentation of the applicant's immigration status. In other states, the effect of the requirement for the applicant to disclose his or her immigration status is more ambiguous because it simply asks for that person's citizenship or nationality (i.e., Alaska, Delaware, or Iowa) but not specifically that person's immigration status, nor does it seek proof of valid immigration status in the U.S. ${ }^{73}$ There are, however, a few states or territories, including California, American Samoa, the District of Columbia, Hawaii, Illinois, Indiana, and Massachusetts, that do not ask for a person's immigration status at all, although some do ask for a person's social security number. Depending on how inflexible that state is with the social security requirement, it could be possible for recent law graduates to sit for the bar in some of these states without regard for their immigration status. Mexican-born Sergio García is one such public example since, though he is undocumented, he sat for the California bar examination and passed it in July 2009 and now seeks admission to the California bar. ${ }^{74}$

68. See infra Appendix A for 50-state survey of Bar admission rules.

69. Id.

70. Id.

71. Tex. Gov'T CODE ANN. § 82.0271 (West 2009). "Residency or Citizenship Status of Applicant. A person who has applied to take the bar examination may not be denied admission to the bar examination based on the applicant's lack of: (1) permanent residency in the United States; or (2) United States citizenship." Id.

72. See infra Appendix A.

73. Id.

74. Ruxandra Guidi, California Bar Considers Admitting Undocumented Immigrant, FRONTERAS (July 29, 2011), http://www.fronterasdesk.org/news/2011/jul/29/california-statebar-consider-undocumented-immigra/. 
Asking for a social security number in bar applications could be an impediment to bar admission but only if the requirement is inflexible, which is not always the case. The social security number requirement could arise as well in other prerequisites to bar admission, such as sitting for the Multistate Professional Responsibility Examination ("MPRE"). The National Conference of Bar Examiners administers the $\mathrm{MPRE}^{75}$ and its guidelines provide that

[t]he examinee must know his or her Social Security number when reporting to the test centers, as this information is requested on the answer sheet. If an examinee does not fill in the corresponding ovals on the answer sheet for his or her Social Security number, he or she may be assigned an identification number for processing and record-keeping purposes. This number will appear on the score report in the space for the Social Security number. ${ }^{76}$

Accordingly, undocumented law graduates will be able to take the MPRE because they will be assigned an identification number in lieu of a social security number.

Like the MPRE, some state bar rules that require a social security number also provide flexibility. The California rule provides that " $[t]$ he applicant is required by law either to provide the Committee with a Social Security Number or to request an exemption because of ineligibility for a Social Security Number."77 Thus state rules on immigration status and requests for social security numbers vary from state to state. A law school that adopts a policy that denies admission based on a particular state's bar examination rules would effectively prevent a student from attending law school and possibly taking the bar in a state that has rules that are more friendly to undocumented bar applicants. Accordingly, a law school should not discriminate against undocumented applicants based on their ability to sit for a particular bar examination.

75. All states other than Washington and Louisiana use the MPRE. The District of Columbia, Guam, Northern Marian Islands, Palau, and Virgin Islands also use the MPRE. 2010 Statistics, BAR EXAMINER, Mar. 2012, at 6, 31, available at http://www.ncbex.org/assets/ media files/Statistics/2010Stats110111.pdf.

76. NAT'L CONFERENCE OF BAR EXAM'Rs, 2012 Multistate Professional RESPONSIBILITY EXAMINATION INFORMATION BOOKLET 7, available at http://www.ncbex.org/ assets/media_files/Information-Booklets/MPREIB2012.pdf.

77. CaL. State Bar R. 4.16(B) (West 2011). 


\section{b. State Character and Fitness Rulings Applicable to Undocumented Law Graduates}

Another significant impediment to admission to the Bar are the character and fitness tests and oaths associated with the bar application. Under character and fitness requirements, bar candidates must possess good moral character and fitness to practice law. Different states have established various criteria that make an applicant unfit to practice law. Undocumented immigrant law students may face challenging issues related to character and fitness requirements when applying for admission to the Bar. For many undocumented law students, ordinary everyday living in the United States requires that they engage in acts that are unlawful under federal immigration law, or increasingly under state law: ${ }^{78}$ living and working in the U.S. without authorization; procuring false immigration and other types of identification to live and work in the U.S.; or lying about their immigration status or place of residence to obtain certain benefits, such as a driver's license, to cite a few examples. Some of the criteria that may impact undocumented law students thus could include, acts involving dishonesty, fraud, deceit or misrepresentation and neglect of financial responsibilities, such as failure to file taxes. In addition, most states, like Alabama, place the burden on the applicant to establish to the reasonable satisfaction of a majority of the bar committee that he or she possesses the character and qualifications to justify his or her admission to the Bar and that he or she can perform duties as an attorney. ${ }^{79}$

This section discusses the general character and fitness rules and background investigations that apply to bar applicants that may impact an undocumented student's ability to gain admission into the Bar. Instead of surveying all states, this section focuses on California, Texas, New York, Florida, and Arizona as a cross-section of character and fitness bar practices. The section continues with a survey of case law on character and fitness requirements in these states. It should be noted that case law on the subject is relatively scarce, with no cases that specifically address the plight of undocumented students. Court opinions regarding related issues of other applicants, however, may be useful in extrapolating issues that may be problematic for the undocumented law student applying for admission to the Bar in any of the five aforementioned states.

78. See JOHNSON ET AL., UNDERSTANDING IMMIGRATION LAW 117-75 (2009).

79. Rules Governing Admission to the Ala. State Bar R. V, at 17 (Aug. 2011), available at http://www.alabar.org/admissions/files/Admissions-Rules-updated_10312011.pdf. 
i) Good Moral Character Requirements for Admission into Bar Generally

All fifty states have character and fitness rules for Bar admission. For example, California's rule states that "[a]n applicant must be of good moral character as determined by the Committee. The applicant has the burden of establishing that he or she is of good moral character." Examiners ("Board") determines whether an applicant possesses the requisite good moral character and, therefore, whether to recommend the applicant for admission to the Bar. ${ }^{81}$ However, the applicant has the burden of proving his or her good moral character to the board by furnishing enough evidence to make a prima facie case. ${ }^{82}$

When the applicant fails to convince the Board that he or she possesses the requisite moral character to practice law, the Board "has a duty not to certify his [or her] name to [the] court for admission" to the Bar. ${ }^{83}$ If the Board presents evidence of bad moral character, the applicant must demonstrate sufficient rehabilitation and moral qualifications to practice law. ${ }^{84}$ Reasonable doubts are typically resolved in favor of the applicant. ${ }^{85}$ According to the California court in Siegel v. Committee of Bar Examiners, ${ }^{86}$ "if two or more equally reasonable inferences may be drawn from a proved fact, the inference leading to a conclusion of innocence rather than the one leading to a conclusion of guilt will be accepted." ${ }^{197}$ When the

80. CAL. State Bar R. 4.40(A) (West 2011); see also N.Y. COMP. CODEs. R. \& Regs. tit. 22, § 520.12(a) (2010). New York's rule states:

Every applicant for admission to practice must file with a committee on character and fitness appointed by the Appellate Division of the Supreme Court affidavits of reputable persons that applicant possesses the good moral character and general fitness requisite for an attorney and counselor-at-law as required by section 90 of the Judiciary Law. The number of such affidavits and the qualifications of persons acceptable as affiants shall be determined by the Appellate Division to which the applicant has been certified.

Id. To be admitted to the Bar in California, Texas, New York, Florida, or Arizona, an applicant must possess the good moral character and fitness required for an attorney and counselor at law. See In re Hamm, 123 P.3d 652, 655-56 (Ariz. 2005) (en banc); In re Walker, 539 P.2d 891, 894 (Ariz. 1975) (en banc); Pacheco v. State Bar of Cal., 741 P.2d 1138, 1139 (Cal. 1987); Fla. Bd. of Bar Exam'rs re J.H.K, 581 So. 2d 37, 39 (Fla. 1991); In re Cassidy, 268 A.D. 282, 284 (N.Y. App. Div. 1994); Texas State Bd. of Law Exam'rs v. Malloy, 793 S.W.2d 753, 756 (Tex. App. 1990).

81. Bd. of Law Exam'rs v. Stevens, 868 S.W.2d 773, 776 (Tex. 1994).

82. Pacheco, 741 P.2d at 1139; In re Greenberg, 614 P.2d 832, 834 (Ariz. 1980) (en banc); Walker, 539 P.2d at 894; In re Fla. Bd. of Bar Exam'rs, 373 So. 2d 890, 891 (Fla. 1979).

83. Greenberg, 614 P.2d at 834; In re Klahr, 433 P.2d 977, 979 (Ariz. 1967) (en banc).

84. In re Menna, 905 P.2d 944, 949 (Cal. 1995).

85. Id. at $949-50$.

86. Siegel v. Comm. of Bar Exam'rs, 514 P.2d 967 (Cal. 1973) (en banc) (distinguished by Smith v. State Bar, 212 Cal. App. 3d 971 (1989)).

87. Id. at 979 . 
Board makes an adverse character and fitness determination, the applicant bears the burden of proof by showing a lack of substantial evidence to support the Board's decision. ${ }^{88}$ Good moral character is defined as "qualities of honesty, fairness, candor, trustworthiness, observance of fiduciary responsibility, respect for and obedience to the law, and respect for the rights of others and the judicial process." $" 89$ The North Carolina court in In re Farmer determined that good moral character:

is something more than an absence of bad character. It is the good name which the applicant has acquired, or should have acquired, through association with his [or her] fellows. It means that he must have conducted himself as a man [sic] of upright character ordinarily would, should, or does. Such character expresses itself, not in negatives nor [sic] in following the line of least resistance, but quite often in the will to do the unpleasant thing if it is right, and the resolve not to do the pleasant thing if it is wrong. ${ }^{90}$

Texas requires that the applicant's good moral "[character] traits must have a rational connection with the Applicant's present fitness or capacity to practice law and accordingly must relate to the legitimate interests of Texas in protecting prospective clients and in safeguarding the system of justice within Texas." 91

In comparison, Florida has developed a specific test to aid its Board in the determination of character and fitness in the bar admissions process. ${ }^{92}$ The Board must resolve two questions when determining the character and fitness of the applicant:

(1) "are the facts ... such that a reasonable [person] would have substantial doubts about the [applicant's] honesty, fairness, and respect for the rights of others and for the laws of the state and nation[, and (2)] is the conduct

88. Unglaub v. Bd. of Law Exam'rs, 979 S.W.2d 842, 845 (Tex. App. 1998).

89. CAL. StAte BAR R. 4.40(B) (West 2011); see also Menna, 905 P.2d at 948 (quoting Rules Regulating Admission to PRACTICE LAW IN CAL. R. X, \& 1). See generally In re Walker, 539 P.2d 891, 895 (Ariz. 1975) (en banc); In re Klahr, 433 P.2d 977, 979 (Ariz. 1967) (en banc); Fla. Bd. of Bar Exam'rs ex rel. R.L.W., 793 So. 2d 918, 925 (Fla. 2001); Fla. Bd. of Bar Exam'rs ex rel. Doe, 770 So. 2d 670, 674 (Fla. 2000); Fla. Bd. of Bar Exam'rs ex rel. M.A.R., 755 So. 2d 89, 92 (Fla. 2000); Fla. Bd. of Bar Exam'rs ex rel. M.R.I., 623 So. $2 d 1178$, 1180 (Fla. 1993); Fla. Bd. Of Bar Exam'rs ex rel. J.H.K., 581 So. 2d 37, 39 (Fla. 1991); Fla. Bd. of Bar Exam'rs ex rel. R.D.I., 581 So. 2d 27 (Fla. 1991) (distinguished by Fla. Bar ex rel. Wolfe, 767 So. 2d 1174 (Fla. 2000)); In re VMF, 491 So. 2d 1104 (Fla. 1986).

90. In re Farmer, 131 S.E. 661,663 (N.C. 1926).

91. Rules GOVERNING ADMISSION TO THE BAR OF TEX. R. IV(b), available at http://www.ble.state.tx.us/Rules/NewRules/ruleiv.htm.

92. Doe, 770 So. $2 \mathrm{~d}$ at 674 . 
involved . . . rationally connected to the [applicant's] fitness to practice law?",93

The second criterion requires a "clear and rational connection between a character trait of the applicant and the likelihood that the applicant would injure a client or obstruct the administration of justice if the applicant were licensed to practice law" in order to support a denial of Bar admission. ${ }^{94}$ In other words, the Board must determine not whether an applicant may repeat past misconduct but whether the misconduct indicates that the applicant's bad character is likely to interfere with disciplinary rules, obstruct justice, or cause injury to a client. ${ }^{95}$ On this point, the Florida court in Board of Law Examiners v. Stevens, stated that:

[a]lthough a lawyer is personally answerable to the entire criminal law, a lawyer should be professionally answerable only for those offenses that indicate lack of those characteristics relevant to his fitness for the practice of law, as "fitness" is defined in these rules. A pattern of repeated offenses, even ones of minor significance when considered separately, can indicate indifference to legal obligation that legitimately could call a lawyer's overall fitness to practice into question. ${ }^{96}$

In connection with the good moral character requirements, states typically require an investigation into the applicant's background. As part of the background check, applicants are typically required to provide their fingerprints. For example, Alabama provides that "[i]f the Committee, during the course of an investigation of the registrant, concludes that a complete set of his or her fingerprints would be of substantial assistance in the investigation, the Committee may direct the registrant to submit a complete set of his or her fingerprints. ${ }^{" 97}$ California and Arizona require that applicants have their fingerprints taken for their character and fitness investigation. $^{98}$ This permits their Character and Fitness Committees to receive criminal history information from law enforcement agencies. ${ }^{99}$

93. Id. (quoting Fla. Bd. of Bar Exam'rs ex rel. G.W.L., 364 So. 2d 454, 459 (Fla. 1978)).

94. Bd. of Law Exam'rs v. Stevens, 868 S.W.2d 773, 776 (Tex. 1994) (emphasis added).

95. Id.

96. Id at 779 .

97. Rules Governing Admission to the Ala. State Bar R. I(B) at 3 (Aug. 2011), available at http://www.alabar.org/admissions/files/Admissions-Rules-updated_10312011.pdf.

98. RULES FOR AdMISSION OF APPLICANTS TO THE PRACTICE OF LAW IN ARIZ. R. 34(d)(6) at 17 (2012) (language of rule states that applicants must submit fingerprints), available at http:/azcourts.gov/Portals/26/admis/2012/Miscellaneous/Rule_of_Admission.pdf.

99. Id. 
ii) Application of Character and Fitness Criteria to Undocumented Students

In this section, we examine what could be implications on character and fitness flowing from law students' immigration violations and other unlawful conduct that directly relates to their survival in the U.S. as undocumented persons. We assess a variety of common examples of conduct that undocumented law students have or could engage in and examine it under three subheadings: unlawful civil conduct, honesty and candor, and criminal conduct.

\section{a) Unlawful Civil Conduct}

One issue that could arise for undocumented law students seeking bar admission is whether a state Bar's admissions committee would find that their undocumented status alone is sufficient to warrant an adverse character and fitness finding. Here are two possible albeit related issues: the unlawful entry into the United States, and the unlawful stay in the United States. We conclude that neither of these factors should warrant denial of character and fitness. To reach this conclusion, we look not only to existing bar rules that could apply but also to treatments of the issue in other legal contexts by the immigration agencies and the courts. The bar rule that would apply here is that each of these constitutes unlawful conduct under federal immigration law and, in a few cases, under state law (though these state criminal laws are likely preempted). ${ }^{100}$ Under federal immigration law, any person, irrespective of age, crossing a border without authorization has committed a civil immigration violation; ${ }^{101}$ however, recognizing the lack of agency for children in crossing a border at a young age, Congress chose not to penalize their unlawful stay in the country until they turn $18 .{ }^{102}$ Following this logic, undocumented law students who were brought to the U.S. as children (prior to their 18th birthday) should not bear the blame for the acts of their parents. Indeed, many undocumented children do not learn the truth about their status until after they graduate from high school. This treatment of the immigration status of undocumented children is consistent with the moral

100. 8 U.S.C. $\S 1325$ (2006) (discussing improper entry by an alien); 8 U.S.C.A. $\S$ $1182(\mathrm{a})(9)(\mathrm{B})(\mathrm{i}-\mathrm{ii})$ (West 2010) (discussing what constitutes an illegal stay by alien in United States). See generally MOdEL RULES OF PROF'L CONDUCT R. 8.4 ("It is professional misconduct for a lawyer to ... commit a criminal act that reflects adversely on the lawyer's honesty, trustworthiness or fitness as a lawyer in other respects [or] engage in conduct involving dishonesty, fraud, deceit or misrepresentation ....").

101. 8 U.S.C. $\S 1325$ (2006).

102. 8 U.S.C.A. $\S 1182(\mathrm{a})(9)(\mathrm{B})(\mathrm{iii})(\mathrm{I})$ (West 2010) (waiving for the purposes of certain grounds of inadmissibility any "period of time in which an alien is under 18 years of age"). 
assessment of the U.S. Supreme Court in Plyler, which decided to treat them as a quasi-suspect class, despite their unlawful immigration status: "[The Texas statute] is directed against children, and imposes its discriminatory burden on the basis of a legal characteristic over which children can have little control. It is thus difficult to conceive of a rational justification for penalizing these children for their presence within the United States." ${ }^{103}$ In evaluating good moral character, for similar reasons, Bar Rules and Committees should use age at the time of conduct and recency of conduct to create, at a minimum, a bright line exemption for the unlawful border crossing of those who came to the U.S. as children.

Of course, in some cases, an applicant might have crossed the border as an adult and, in any event, most if not all applicants to the Bar will be older than 18. In these cases, the illegality of the unauthorized entry into the U.S. is clearer, as is the fact that after 18, anyone remaining in the U.S. without authorization commits a civil immigration violation. Whether this fact is determinative that the person is unfit to practice law is less clear. The fact that a person is violating a law, while relevant to a character and fitness inquiry, is not outcome-determinative. The outcome should instead depend on the nature of the law that has been violated - i.e., its morality vis-à-vis the seriousness of the crime and the harm it produces. In this regard, the morality of our current immigration laws has always been hotly contested. ${ }^{104}$ Particularly for children raised in the U.S., the significant ties they have built here and the identity they have acquired as members of this society make it untenable to expect them simply to return upon turning 18 to countries where many have no remaining family, and do not even speak the language. Here, it is also telling that in deciding issues of good moral character under the immigration laws ${ }^{105}$ no immigration or Article III court has found that unauthorized entry or unauthorized stay in the U.S. is sufficient to find that a person lacks good moral character or constitutes a crime involving moral turpitude. ${ }^{106}$

103. Plyler, 457 U.S. at 220.

104. See generally BILl ONG Hing, DePorting Our Souls: VAlues, Morality, AND IMMIGRATION POLICY (2006); JOHNSON, supra note 17.

105. The Immigration and Nationality Act ("INA") requires good moral character to accord certain immigration benefits, such as admission and naturalization into the U.S. See Lauren Gilbert, Citizenship, Civic Virtue and Immigrant Integration: The Enduring Power of Community-Based Norms, 27 YALE L. \& POL'Y REV. 335, 350-61 (2009) (discussing development of "good moral character" in Part II).

106. The term "good moral character" under the INA generally excludes individuals who have committed violent crimes, are prostitutes, habitual drunkards, or who have committed or been convicted of certain types of crimes involving moral turpitude. 8 U.S.C.A $\S 1101(\mathrm{f})$ (West 2011). The INA does not define what is a crime involving moral turpitude, but over time, immigration agencies and courts have attempted to define the term through cases. See Pooja R. 
Other types of unlawful civil conduct that undocumented law students may have committed prior to seeking admission to the bar that may have some relevance to character and fitness considerations, include working without authorization in the U.S. or committing other minor offenses, such as driving without a license. In deciding how to weigh this type of conduct, bar examiners should consider the reasons why the applicant has engaged in this type of conduct -i.e., for economic survival and out of necessity, and the underlying nature of the act which is only unlawful because of their unauthorized stay in the country and not because of anything inherently immoral or illegal about the underlying conduct (i.e., working and driving). As well, bar committees should consider the choices available to the undocumented law student to comply with the law: For nearly all undocumented law students, any reasonable path to legalization is slim to none, either because they do not qualify for available visas, ${ }^{107}$ or because their unlawful stay in the U.S. bars them from being able to legalize without leaving a country and having to face a bar on returning of at least ten years. ${ }^{108}$ Here, when the only choice to be lawful while living is to leave the U.S. territory, similar considerations related to stakes that compel students to stay should be taken into account. As well, with regard to working in the U.S. without authorization, it might be relevant to consider the treatment of unauthorized employment under federal immigration law. While it is true that the immigration laws authorize only certain types of lawful immigrants (i.e., lawful permanent residents, and certain nonimmigrants), it is also interesting to note that Congress only imposed civil and criminal sanctions on employers for knowingly hiring the undocumented, not on the workers themselves. ${ }^{109}$ Immigrant workers, instead, face only immigration consequences, such as the loss of their nonimmigrant visa or the inability to adjust their status, ${ }^{110}$ for working without authorization. In addition, it is of note that neither working without authorization nor driving without a

Dadhania, The Categorical Approach For Crimes Involving Moral Turpitude After SilvaTrevino, 111 COLUM. L. REV. 313, 315-46 (2011).

107. Undocumented students are unlikely to have family members who can sponsor them and are ineligible for student nonimmigrant student visas because they could not prove financial viability to study in the U.S. See generally SARAH IGNATIUS \& ELISABETH S. STICKNEY, NAT'L IMMIGRATION PROJECT OF THE NAT'L LAWYERS GUILD, IMMIGRATION LAW AND THE FAMILY $\S$ 1:2 (2011); RICHARD D. STEEL, STEEL ON IMMIGRATION LAW \& 3:12 (2011).

108. Austin T. Fragomen, JR. ET AL., LABOR CertifiCATION HANDboOK $§ 2: 20$ (2011).

109. See generally id.

110. Id. 
license has implications on the determination of good moral character under the immigration laws. ${ }^{111}$

Finally, highly adverse judgments in civil litigation can pose a problem for Bar applicants in New York. ${ }^{112}$ Additionally, the Florida admission rule states that a violation of a court order is reason for disqualification from the Bar. ${ }^{113}$ If an undocumented student has a prior order of deportation against him or her, this could exclude him or her from admission into that Bar.

\section{b) Honesty and Candor}

Another character and fitness problem that an undocumented applicant to the Bar may face is a lack of candor or honesty. ${ }^{114}$ Applicants for Bar admission are required to be honest and candid. ${ }^{115}$ This requirement is connected to a lawyer's ability to represent his or her client and uphold the law. The Florida Supreme Court has found that "[n]o qualification . . . is more important than truthfulness and candor" in an applicant. ${ }^{116}$ Untruthfulness is directly related to an applicant's character and fitness, and a pattern of dishonesty in bar application proceedings can warrant a denial

111. A search of immigration cases and good moral character determinations did not yield adverse findings.

112. See, e.g., In re McNallen, 736 N.Y.S.2d 477, 477 (N.Y. App. Div. 2002) (denying admission to candidate whose behavior had been adjudged "beyond the bounds of decency" by a civil jury in another state).

113. Rules of the Sup. Ct. Relating to Admission to the Bar of Fla. R. 3-11(i) (2008), available at http://www.floridabarexam.org/public/main.nsf/rules.html\#3-11.

114. See generally In re Walker, 539 P.2d 891, 895 (Ariz. 1975) (en banc); In re Klahr, 433 P.2d 977 (Ariz. 1967) (en banc); Siegel v. Comm. of Bar Exam'rs, 514 P.2d 967, 970 (Cal. 1973) (en banc) (distinguished by Smith v. Cal. State Bar, 212 Cal. App. 3d 971 (Cal. Ct. App. 1989)); Greene v. Comm. of Bar Exam'rs, 480 P.2d 976, 982-83 (Cal. 1971) (en banc) (distinguished by Smith v. Cal. State Bar, 212 Cal. App. 3d 971 (Cal. Ct. App. 1989)); Spears v. State Bar of Cal., 294 P. 697, 699-700 (Cal. 1930) (distinguished by Hallinan v. Comm. of Bar Exam'rs, 421 P.2d 76 (Cal. 1966)); In re Wells, 163 P. 657, 658 (Cal. 1917) (en banc) (distinguished by In re Rose, 993 P.2d 956 (Cal. 2000)); Fla. Bd. of Bar Exam'rs ex rel. R.L.W., 793 So. 2d 918, 921-27 (Fla. 2001); Fla. Bd. of Bar Exam'rs ex rel. Doe, 770 So. $2 d$ 670, 672 75 (Fla. 2000); Fla. Bd. of Bar Exam'rs ex rel. M.A.R., 755 So. 2d 89, 92 (Fla. 2000); Fla. Bd. of Bar Exam'rs ex rel. M.R.I., 623 So. 2d 1178, 1180 (Fla. 1993); Fla. Bd. of Bar Exam'rs ex rel. J.H.K., 581 So. 2d 37, 38-39 (Fla. 1991); Fla. Bd. of Bar Exam'rs ex rel. R.D.I., 581 So. 2d 27, 28-31 (Fla. 1991) (distinguished by Fla. Bar ex rel. Wolfe, 767 So. $2 d 1174$ (Fla. 2000)); In re V.M.F., 491 So. 2d 1104, 1107 (Fla. 1986); In re Lawrence, 906 N.Y.S.2d 916, 918 (N.Y. App. Div. 2010); In re Anonymous, 785 N.Y.S.2d 129, 130 (N.Y. App. Div. 2004); In re Greenblatt, 2 N.Y.S.2d 569, 572 (N.Y. App. Div. 1938) (distinguished by In re Waters, 447 P.2d 661 (Nev. 1968)); Tex. State Bd. of Law Exam'rs v. Malloy, 793 S.W.2d 753, 755-57 (Tex. App. 1990).

115. In re Steinberg, 528 N.Y.S.2d 375, 378 (N.Y. App. Div. 1988).

116. Doe, 770 So. $2 \mathrm{~d}$ at 674; Steinberg, 528 N.Y.S.2d at 375. 
of admission. ${ }^{117}$ However, in Florida, a lack of honesty does not warrant automatic denial of Bar admission. ${ }^{118}$

Undocumented law students may have previous instances of untruthfulness directly related to their undocumented status. Moreover, Bar admission applications are likely to require that undocumented students disclose any previous instances of dishonesty or lack of candor related to their immigration status. Bar admission applications are likely to require that undocumented students disclose any previous instances of dishonesty or lack of candor related to their immigration status, as well as reveal their current immigration status in some instances. The character and fitness rules require that an applicant not "fail to disclose a fact necessary to correct a misapprehension known by the person to have arisen in the matter, or knowingly fail to respond to a lawful demand for information from an admissions or disciplinary authority." "In the assessment of whether prior acts of dishonesty by undocumented law student applicants adversely affect character and fitness to practice law, state Bar Committees should consider the purpose in or state of mind of the applicant when making an untrue statement. In Siegel v. Committee of Bar Examiners, for example, the California Board found that the applicant had advocated unlawful violence in three speeches made when he was a student. ${ }^{120}$ The applicant, however, maintained that he had not advocated unlawful violence in the speeches, and, as a result, the Board found him to be lying. ${ }^{121}$ The court held that denial of certification in such a case can be upheld only when the applicant's version of the facts is objectively false, beyond a reasonable doubt, and that the applicant advanced the false version of the facts with the intent to deceive the Board. ${ }^{122}$ The court defined the term "to lie" as "to make an untrue statement with [the] intent to deceive." ${ }^{\prime 23}$ Therefore, the court reasoned that:

the determination of whether a lie has been told comprehends an analysis having two aspects: (1) an objective aspect, which is concerned with whether an 'untrue statement' has been made, and (2) a subjective aspect, which is concerned with the intent or state of mind of the person who utters such a statement. The first of these aspects logically precedes the second, for if there has been

117. M.A.R., 755 So. $2 \mathrm{~d}$ at $92 ;$ J.H.K., 581 So. $2 \mathrm{~d}$ at 39.

118. Fla. Bd. of Bar Exam'rs ex rel. L.M.S., 647 So. 2d 838, 839 (Fla. 1994).

119. ARIZ. SUP. CT. R. 42; MODEL RULES OF PROF'L CONDUCT R. 8.1(b).

120. Siegel, 514 P.2d at 973.

121. Id. at $973-74$.

122. Id. at 983.

123. Id. at 980; WEBSTER's NEW INT'L. DiCTIONARY 1305 (3d ed. 1963). 
no untrue statement made, inquiry into the speaker's state of mind becomes irrelevant. ${ }^{124}$

The court ultimately determined that the speeches did not advocate unlawful violence; therefore, the objective aspect of the lie-test was not met since the applicant's statements were not untrue. ${ }^{125}$ As a result, the court ordered the Board to certify the good moral character and fitness of the applicant. ${ }^{126}$

One example of dishonesty that may be common for undocumented law students is having relied on false documents to obtain employment in the U.S. or to conduct other daily living business, such as opening a bank account, or renting an apartment, driving a car, etc. It would not be uncommon that some of these false documents may have been obtained for the student by the parent or other family members when the student was still a child. ${ }^{127}$ Still, it would be common that the student used these documents as an adult, which would still involve dishonesty and sometimes the commission of an additional unlawful act. For example, in the procurement of false identification, the applicant may have potentially committed other unlawful acts related to identity theft or fraud if any of the identification numbers used (i.e., social security numbers, name) belonged to someone else. In most cases, however, the undocumented law student is unlikely to have known that any of the information in the false identification documents belonged to someone else. This should matter in the analysis of character and fitness in similar ways that it has mattered under immigration and criminal laws. As already mentioned, under immigration law, working without authorization, while it violates visa immigration requirements, does not result in additional fines or penalties for the worker nor, perhaps more importantly, in a finding that the person lacks good moral character. ${ }^{128}$ Moreover, in a recent U.S. Supreme Court case on point, Flores-Figueroa v. United States, ${ }^{129}$ the Court found that a Mexican national did not violate federal identity theft for providing his employer with a false name, birth date, and Social Security number, along with a counterfeit alien registration card, where he did not know that the social security number and alien registration numbers were in fact assigned to others. There is no denying

124. Siegel, 514 P.2d at 980.

125. Id. at 983 .

126. Id. at 984 .

127. See, e.g., Jose Antonio Vargas, My Life as an Undocumented Immigrant, June N.Y. TiMES, June 26, 2011, at MM22, available at http:/www.nytimes.com/2011/06/26/magazine/ my-life-as-an-undocumented-immigrant.html?pagewanted=all.

128. See supra notes $102-03$ and accompanying text.

129. Flores-Figueroa v. United States, 556 U.S. 646 (2009). 
that presenting false documents to an employer to procure a job, whether or not the undocumented student was aware of the identity theft issues, is dishonest. The issue here becomes whether a Bar Committee should consider the dire circumstances facing undocumented law students, particularly those raised in the United States from a very young age who must work to survive and be productive members of U.S. society or be forced into exile in a country they know little about and where they have few to no connections. Additional scenarios may be present, for example, when the applicant takes affirmative steps to make misrepresentations to state agencies in order to obtain fraudulent documents. Such is the case, for example, when undocumented immigrants living in another state may go to a different state where licenses for undocumented immigrants are permitted and lie about their place of residence to obtain a license. ${ }^{130}$ Here too, not having a driver's license in the United States is extremely difficult, which has prompted scholars to view the denial of driver's licenses to undocumented immigrants as a civil rights crisis. ${ }^{131}$ Driving in most cities in the United States is a necessity to conduct most essential daily tasks, but it is also necessary to such basic life functions as opening a bank account, obtaining credit, and renting an apartment. There is a strong claim, therefore, that laws denying driver's licenses to undocumented immigrants, particularly undocumented students brought to the U.S. as children with deep and significant stakes in this country, are morally deficient. The challenge, however, is whether in deciding whether to admit lawyers into the profession, Bar Examiners should consider not only significant humanitarian factors that might push applicants to commit acts of dishonesty but also misrepresentations that could be characterized as acts of civil disobedience. ${ }^{132}$

Some courts have denied admission into the Bar based on misrepresentations that a student has made during the course of his or her academic career. ${ }^{133}$ Courts have found that this materially affects eligibility for admission. For example, in the California case, In re Wells, the Bar

130. See, e.g., Marc Lacey, License Access in New Mexico Is Heated Issue, N.Y. TIMES, Aug. 24, 2011, at A1, available at http://www.nytimes.com/2011/08/24/us/24licenses.html.

131. Kevin R. Johnson, The End of "Civil Rights" as We Know It?: Immigration and Civil Rights in the New Millennium, 49 UCLA L. REV. 1481, 1503-08 (2002).

132. See generally David Luban, LAWYERs AND Justice: AN ETHICAL STUdy (1988); William H. Simon, THE PRACTICE OF JustiCE: A THEORY OF LAWYERS' ETHICS (1998).

133. In re Greenblatt, 2 N.Y.S.2d 569, 570 (N.Y. App. Div. 1939) (distinguished by In re Waters, 447 P.2d 661 (Nev. 1968)). 
applicant concealed material facts in order to obtain a school loan. ${ }^{134}$ The court held that the applicant's conduct showed a lack of honesty and good character; therefore, the court denied the applicant's application for admission to the Bar. ${ }^{135}$ Comparably, the applicant in Florida Board of Bar Examiners re M.R.I. falsely claimed to have earned forty-five credit hours at the University of Havana when she applied for admission to her undergraduate college. ${ }^{136}$ In order to make her attendance at the University of Havana more believable, she stated that her year of birth was 1944 rather than $1948{ }^{137}$ She made the same false statements regarding her university attendance and year of birth on her application to law school. ${ }^{138}$ Furthermore, she made false statements at a Board hearing by falsely accusing an employee at the University of Havana of instructing her to falsify her educational qualifications and date of birth. ${ }^{139}$ The court held that the applicant's misconduct and lack of candor rendered her ineligible for admission to the Bar. ${ }^{140}$

134. In re Wells, 163 P. 657, 660 (Cal. 1917) (distinguished by In re Rose, 993 P.2d 956 (Cal. 2000)). Also, when working for an attorney, the applicant advised witnesses in a case to evade the truth when testifying at trial. $I d$.

135. Id. at 661 .

136. Fla. Bd. of Bar Exam'rs ex rel. M.R.I., 623 So. 2d 1178, 1178 (Fla. 1993).

137. Id.

138. Id.

139. Id. at 1179 .

140. Id. at 1180; see also Fla. Bd. of Bar Exam'rs ex rel. R.L.W., 793 So. 2d 918, 920-21 (Fla. 2001) (The applicant failed to disclose attendance at Western State University College of Law ("Western State") as required in his Bar admission application; failed to disclose his delinquent account at Western State; failed to disclose attendance at Western State and his delinquent account as required in a supplement to his Bar admission application; falsely testified at a Board hearing that he had no recollection of attendance at Western State at the time he filled out the Bar admission application and supplement; failed to disclose attendance at Western State as required in his application to Saint Louis University School of Law ("Saint Louis"); falsely stated his reasons for withdrawing from Western State in a letter to Saint Louis; made false statements in his student Bar registration application regarding his marital status; failed to disclose in his student Bar registration application his attendance at Western State; falsely stated in his Application for Certification of Fitness to Practice Law in Georgia that he had never been divorced when he had been divorced in 1996; failed to disclose in his Georgia Bar application that he had submitted an application for Bar admission in Florida; made false statements in his Georgia Bar application regarding an account that had been turned over to a collection agency; failed to disclose in his Georgia Bar application that he had been a party to litigation when he had been divorced; falsely stated in his Georgia Bar application that he had never been charged with a traffic violation when he had received a speeding ticket in 1994; misrepresented to the Georgia Bar his reason for withdrawing from Western State; and failed to disclose attendance at Western State in his Graduate Application for Admission to Suffolk University's Master of Business Administration program. Furthermore, he arrived at the Board hearing with a copy of the Georgia Bar application that had been altered to conceal discrepancies and therefore did not match the Board's copy of the application. Notably, the court stated that the applicant's conduct "is a perfect example of what one should not do if one wishes to be admitted to the practice of 
Some undocumented students may have provided false information as well during the course of their academic studies, such as providing false identification or a false social security number on an admissions application. Here, Bar Committees should consider the state of mind the student when providing the information as well as whether the provision of the information served only minor instrumental purposes-e.g., the use of the identification to assign a student ID number - or if it became a basis for the student to obtain benefits to which he or she was not entitled. In most cases, at least when applying to college, it is unlikely that an undocumented student would know why a school is asking for a social security number in a college admission application, for example, and could very reasonably believe that its sole purpose is to have the number used to assign a student record. It is also unlikely, unless the school is explicit in providing this type of information, that the undocumented student would know all the intricacies of whether that state allows admission to undocumented students, in-state tuition, or other financial benefits, or know what the law is as to availability of federal financial aid and student loans. For example, in all instances, to apply for federal financial aid, a separate form must be filled out, usually electronically, and the validity of the social security number is subject to verification. ${ }^{141}$ Moreover, for schools that restrict instate tuition and even admission to students with lawful immigration status, ${ }^{142}$ that verification process is also likely to be part of the application. To a Bar Committee, what should be relevant is whether the undocumented student understood the implications of providing false identification information and intended to deceive the school to benefit in ways that are not permitted by law. As well, a relevant inquiry would be if the student sought to rectify the false information provided as soon as possible after the student became aware of how it would be used.

In addition, the making of false or misleading statements on bar admissions applications in particular shows a lack of good moral character. ${ }^{143}$ In Greene v. Committee of Bar Examiners, the applicant made false statements in his Bar admission application regarding his state of

law in Florida. This is a classic example of what should not be done by a future lawyer." As a result of the aforementioned misconduct, the court denied the applicant admission to the Florida Bar).

141. In fact, the undocumented students risk possible fraud charges and deportation for submitting a financial aid form request and are strongly advised against it. See, e.g., 6 Tips for Counseling Undocumented AB 540 Students, FutUROS EdUC. SERVICES, available at http://www.calgrants.org/index.cfm?navid=213 (last visited Jan 27, 2011).

142. See supra Part II.B.

143. Greene v. Comm. of Bar Exam'rs, 480 P.2d 976, 979-84 (Cal. 1971) (en banc) (distinguished by Smith v. State Bar, 212 Cal. App. 3d 971 (Cal. Ct. App. 1989)). 
residency. He also omitted his previous attendance at New York University Law School, as well as the fact that he had applied to take the New York Bar Examination, although the California Bar admission application explicitly requested that information. ${ }^{144}$ Moreover, the applicant made false statements with respect to his legal practice experience in other states. ${ }^{145}$ The applicant also omitted information regarding an annulment to which that he was a party; however, the California Bar admission application explicitly requested information about involvement in any civil proceedings. ${ }^{146}$ Lastly, the applicant failed to include in his application any information regarding a previous warrant for his arrest for the non-support of the other party to the annulment. ${ }^{147}$ Due to his many false statements, the court denied the applicant's application for admission to the practice of law in California. ${ }^{148}$ Another Bar applicant in Florida Board of Bar Examiners ex rel. Doe similarly failed to disclose a pending charge for criminal battery on his law school application. ${ }^{149}$ Additionally, in his application for the Florida Bar and at a related hearing, he falsely denied being been excluded from further law studies after failing two law courses. ${ }^{150} \mathrm{He}$ also falsely denied being accused of an honor code violation in his application for the Bar when in fact he had been accused of cheating in law school, a violation of the school's honor code. ${ }^{151}$ The court concluded that the applicant showed a lack of candor in his Bar application, and therefore denied him admission. ${ }^{152}$ The applicant in In re Greenblatt falsely claimed in his Bar application that he had withdrawn from the University of Maryland once he had earned sufficient credits to attend law school; however, the University had in fact requested the applicant to withdraw after he performed poorly in several courses and was accused of an honor code violation when he cheated on an examination. ${ }^{153}$ The applicant also sent a letter to the University requesting that the reason he did not earn a degree be listed as "[d]id not finish course" or "[s]tudent left" rather than indicate that the University had in fact dropped him as a student. ${ }^{154}$ Due to the applicant's

144. Id. at 979 .

145. Id. at $979-80$.

146. Id. at 982.

147. Id.

148. Id. at 984.

149. Fla. Bd. of Bar Exam'rs ex rel. Doe, 770 So. 2d 670, 672 (Fla. 2000).

150. Id.

151. Id.

152. Id. at 674-75.

153. In re Greenblatt, 2 N.Y.S.2d 569, 571-72 (N.Y. App. Div. 1938) (distinguished by In re Waters, 447 P.2d 661 (Nev. 1968)).

154. Id. at 571 . 
repeated attempts to deceive the Board, as well as his attempt to involve the University in the deception, the court denied his application for admission to the Bar. ${ }^{155}$

\section{c) Criminal Conduct}

Also, in order to be considered of good moral character for Bar admission, an applicant cannot have a record of convictions of crimes involving moral turpitude. ${ }^{156}$ Moral turpitude connotes a "fraudulent or dishonest intent." 157 A crime that includes the intent to defraud is, therefore, one that involves moral turpitude. ${ }^{158}$ Whether a crime involves moral turpitude is a question of law for the court to determine. ${ }^{159}$ Crimes of moral turpitude that may apply to undocumented students based on their status include conviction for identity fraud, for example applying for or obtaining a driver's license with a false name or address. ${ }^{160}$ Under the case law and depending on the mitigating factors, solely committing crimes of moral turpitude could prevent an applicant from being admitted to the Bar. ${ }^{161} \mathrm{~A}$ Bar admission committee may view failure to disclose undocumented status or being unlawfully within the country as a crime of moral turpitude.

Florida takes a more categorical approach in making character and fitness requirements by excluding applicants convicted of certain categories of crimes. An applicant cannot be a convicted felon, serving on felony probation, or previously found unqualified by the Florida Admissions Board. ${ }^{162}$ Further, the Texas court in Hallinan v. Committee of Bar Examiners stated that the determination of good moral character "usually turns upon whether [the applicant] has committed or is likely to continue to commit acts of moral turpitude."163 The court in Muniz v. Texas defined "moral turpitude" as "anything done knowingly contrary to justice, honesty, principle, or good morals. It has also been defined to be an act of baseness, vileness, or depravity in the private and social duties which a [person] owes

155. Id. at 572 .

156. Bd. of Law Exam'rs v. Stevens 868 S.W.2d 773, 776 (Tex. 1994); Hallinan v. Comm. of Bar Exam'rs, 421 P.2d 76, 81 (Cal. 1966) (distinguished by In re Gossage, 5 P.3d 186,196 (Cal. 2000)).

157. State Bar v. Heard, 603 S.W.2d 829, 835 (Tex. 1980).

158. Id.

159. Id.

160. See generally Bd. of Bar Exam'rs ex rel. R.D.I., 581 So. 2d 27 (Fla. 1991) (distinguished by Fla. Bar ex rel. Wolfe, 767 So. 2d 1174 (Fla. 2000)).

161. See generally R.D.I., 581 So. $2 \mathrm{~d} 27$.

162. Rules OF THE SUP. CT. RELATING TO ADMISSION TO THE BAR OF FLA. R. 2-13.3 to .5 (2008).

163. Hallinan v. Comm. of Bar Exam'rs, 421 P.2d 76, 81 (Cal. 1966) (distinguished by In re Gossage, 5 P.3d 186 (Cal. 2000)). 
to his [or her] fellow [people] or to society in general."164 The court in Muniz also stated that the nature of the offense as it reflects on the applicant's moral character and fitness is to be considered in the determination of whether a crime involves moral turpitude. ${ }^{165}$ When the applicant has committed crimes that do not involve moral turpitude per se, "investigation into the circumstances surrounding the commission of the act must reveal some independent act beyond the bare fact of a criminal conviction to show that the act demonstrates moral unfitness and justifies exclusion or other disciplinary action by the [B]ar." 166

\section{d) Filing Taxes}

Although they can pay taxes in their own names using an Individual Taxpayer Identification Number (ITIN), another issue that undocumented law students may face is the failure to file or pay income taxes. The American Bar Association Model Rules of Professional Conduct lists revenue offenses, such as fraud and tax evasion, as those that "reflect adversely on fitness to practice law." 167 For undocumented student bar applicants, who do not have authorization to work in the United States, it is likely that they may not have filed income taxes with the state or federal government. ${ }^{168}$ This may adversely affect any Bar application. The Texas court in In re Humphreys held that federal tax evasion is an intentional crime involving moral turpitude, and the attorney was disbarred. ${ }^{169}$ Similarly, the applicant in Stevens failed to file income tax returns for fourteen years. ${ }^{170} \mathrm{He}$ also failed to disclose this information as required on his application for admission to the Bar. ${ }^{171}$ The court held that a clear and rational connection existed between the failure to file income taxes for

164. Muniz v. Texas, 575 S.W.2d 408, 411 (Tex. Civ. App. 1978).

165. Id.

166. Hallinan, 421 P.2d at 85 . In a 1978 opinion, the Supreme Court of Florida held that a self-identifying homosexual would be permitted entry into the bar, where he had not been questioned about and therefore had provided no information as to actual and then-illegal acts of sodomy. See In re Florida Bd. of Bar Exam'rs, 358 So. 2d 7 (Fla. 1978). Over the dissent (" $[\mathrm{t}]$ here should not be admitted to The Florida Bar anyone whose sexual life style contemplates routine violation of a criminal statute."), the majority believed that the applicant was qualified for admission. $I d$. at 10 .

167. In re Humphreys, 880 S.W.2d 402, 407 (Tex. 1994) (citing Model RULES OF Prof'L CONDUCT R. 8.4 cmt. 2 (1992)).

168. See generally In re Greenberg, 614 P.2d 832 (Ariz. 1980) (en banc); In re Humphreys, 880 S.W.2d 402 (Tex. 1994) (distinguished by In re Caballero, 272 S.W.3d 595 (Tex. 2008)); Bd. of Law Exam'rs v. Stevens, 868 S.W.2d 773 (Tex. 1994).

169. Humphreys, 880 S.W.2d at 409.

170. Stevens, 868 S.W.2d at 774.

171. Id. 
fourteen years and the "probability that [the] applicant would injure clients or violate ethical rules were he admitted to practice in Texas."172 Therefore, the court denied the applicant's application for admission to the Bar. ${ }^{173}$

The Texas court in Board of Law Examiners $v$. Stevens stated that the willful failure to file an income tax return is a crime of moral turpitude that indicates a marked disrespect for the law, a lack of financial responsibility, and the "persistent inability to discharge, or unreliability in carrying out, significant obligations." 174 An undocumented student who has worked while in the United States but has not filed any tax returns could be found to have committed a crime of moral turpitude that would make him or her inadmissible to the Bar.

Here, however, Bar committees might consider the treatment of tax filings under immigration law, which has been considered relevant to establishing good moral character when, inter alia, applying for naturalization, cancellation of removal, or to adjust status. ${ }^{175}$ Under immigration proceedings, moreover, applicants who have not filed taxes are given the opportunity to back pay taxes, provided they pay all penalties and fees associated with late filings. While this can be expensive for applicants, it has functioned to remedy any past omissions to file tax returns in immigration proceedings. ${ }^{176}$ Undocumented law students, therefore, can and should be current in their taxes when applying for admission to any Bar.

\section{Law School's Duty and Commitment to Diversity the Profession}

In spite of their mandate not to use admission policies to preclude the recruitment and retention of diverse students and stated commitment to admit policies and practices that aim to increase the diversity of the

172. Id. at 781 .

173. Id.

174. $I d$.

175. See, e.g., Yaqub v. Gonzalez, No. 1:05-cv-170, 2006 U.S. Dist. LEXIS 36727 (S.D. Ohio June 5, 2006) (granting a Pakistani man's application for naturalization, on the grounds that his successful educational and employment endeavors, his future employment prospects, and his positive community contributions all show he "has been and still is a person of good moral character" within the meaning of the statute); In re Arreguin, 21 I \& N Dec. 38, 41 (B.I.A. 1995) (granting relief under INA former section 212(c) to a woman in deportation proceedings, considering, among other factors, the applicant's long history of employment, payment of taxes, and the prospect of full-time employment upon her release).

176. See Lilah S. Rosenblum, Mistakes in the Making: The Failure of U.S. Immigration Reform to Protect the Labor Rights of Undocumented Workers, 13 HUM. RTS. BRIEF, no. 3, 2006 at $23,26$. 
profession as members of the ABA and the AALS, ${ }^{177}$ law schools and, consequently the legal profession, continue to face a diversity gap in the admission and graduation of lawyers of color. In 2010, an ABA Report titled Diversity in the Legal Profession: The Next Steps, listed some disappointments, including that the legal profession remains less diverse than most other professions and that, in 2000, the legal profession was still about $90 \%$ Caucasian without much progress since. ${ }^{178}$ Also a website called A Disturbing Trend in Law School Diversity, a product of the Columbia University School of Law and the Society of American Law Teachers, reports that in the past fifteen years, law school admission has dropped with regard to African Americans and Mexican Americans, despite the fact that these groups have been applying to schools in relatively constant numbers and have improved performance on leading indicators used by law schools to determine admissibility (i.e., LSAT and undergraduate GPA). ${ }^{179}$

Of course, the admission of undocumented law students, given the small size of the population, will neither solve the reasons why law schools and the legal profession lag in diversity, nor fully remedy the problem. However, the refusal to admit undocumented students must be understood as bearing on diversity. Professor Kevin Johnson, the Dean of University of California, Davis, recognizes the impact the failure to admit undocumented students will have on law school diversity. In his paper, The Importance of Student and Faculty Diversity at Law Schools: One Dean's Perspective, Dean Johnson states:

In recent years, a related issue touching on racial diversity in higher education has emerged. The access of undocumented immigrant students, who are not eligible for most federally insured

177. See supra notes $42-45$.

178. Diversity IN THE LegAL Profession: THE NeXT StePS, supra note 18.

179. There was a $7.5 \%$ decrease in the proportion of African-American in the 2008 class as compared with the 1993 class. For Mexican-Americans, there was a $11.7 \%$ decrease in the proportion entering law school as compared to 15 years ago. See Conrad Johnson, A Disturbing Trend in Law School Diversity, Colum. Univ. Sch. of L. Blog (2009) http://blogs.law.columbia.edu/salt/. But see E-mail from Stephen T. Schreiber, Exec. Vice President, Law School Admission Council, to deans, LSAC response to Disturbing Trend in Law School Admissions (Jan. 14, 2010), available at http://www.saltlaw.org/userfiles/1-1410LSACResponse.pdf, stating that diversity among matriculants in law schools have consistently increased over the past several years [2001-2008], even taking into account some negative variability in some of the years. In response, Conrad Johnson of Columbia Law School, a principal author of the website, did not amend his assertions and noted, in fact, that the data provided by LSAC confirmed the data that while diversity across all groups has modestly increased over the years, not so for Mexican and African Americans. See E-mail from Conrad Johnson, Prof. of Law, Columbia Univ., to dean, Response from Conrad Johnson to dean's listserve message from Daniel Bernstine of LSAC (Jan. 15, 2010), available at http://www.saltlaw.org/userfiles/CJ\%20response $\% 20$ to $\% 20$ listserve $\% 20 \mathrm{~b} \% 20$-final(3).pdf. 
loan and other programs, to public colleges and universities has become a deeply controversial issue. This is not simply an issue of access to higher education but is inextricably entangled with the ongoing national debate over immigration reform. The access of undocumented students to public colleges and universities has consequences for the diversity of the student bodies, given that many undocumented students initially came-some when they were young children-from Latin America and Asia and are people of color as we understand that term in the United States. ${ }^{180}$

Dreamies, a term used to refer to students who would benefit from the DREAM Act, come from everywhere. According to DREAMActivist.org, an online recourse network for undocumented students, there are "black dreamies, brown dreamies, yellow dreamies, white dreamies - a rainbow full of dreamies." 181

An important backdrop for the diversity implications in higher education that flow from U.S. immigration policies is the United States' long history of professional and educational exclusion of racialized categories of "nonpersons." Based on its 1912 resolution that read "It has never been contemplated that members of the colored race be members of the association," the American Bar Association had an official policy of excluding African Americans until 1943. ${ }^{182}$ Following a history of actively supporting segregation and local exclusion of people of color, the American Medical Association excluded African American physicians until 1968. ${ }^{183}$ This history is credited with the modern paucity of African American doctors and racial health disparities in the United States. ${ }^{184}$ The story of Pennsylvania's first African American bar member vividly illustrates this history of professional exclusion. When Jonathan Jasper Wright first sought entry to a bar association in his home state of Pennsylvania in 1864, he was informally warned off applying. ${ }^{185}$ The judge who had blocked his entry then left the bench, and Wright made a second attempt in 1866, this time

180. Kevin R. Johnson, The Importance of Student and Faculty Diversity at Law Schools: One Dean's Perspective, 96 Iowa L. REV. 1549, 1572 (2011).

181. Beleza Chan, Not Just a Latino Issue: Undocumented Students in Higher Education, J. College Admission, Winter 2010, at 29.

182. Sixty Years after Admitting Its First Black Member, the American Bar Association Elects an African-American President, 35 J. BLACKS HigHer Educ. 34, 34 (2002).

183. Robert B. Baker, et al., African American Physicians and Organized Medicine, 1846 1968: Origins of a Racial Divide, 300 J. AM. MED. Ass'N 306 (2008).

184. Id.

185. Richard Gergel \& Belinda Gergel, "To Vindicate the Cause of the Downtrodden:" Associate Justice John Jasper Wright and Reconstruction in South Carolina, in AT FREEDOM'S DOOR: AFRICAN AMERICAN FOUNDING FATHERS AND LAWYERS IN RECONSTRUCTION SOUTH CAROLINA 36, 38 (2000). 
gaining entry and becoming Pennsylvania's first African American lawyer. ${ }^{186}$ The local newspaper decried Wright's "impudence" and the "modern radical doctrine of equality" that had led to his admission to the state bar. ${ }^{187}$ Finally discouraged by his treatment in Pennsylvania, Justice Wright relocated to forge a life of distinguished service in South Carolina. ${ }^{188}$

Racialized exclusion from education is another marked theme of American life. As Professor John Park notes:

[P]ublic law has always governed access to educational opportunities by race and status in the United States.[For example,] although education was forbidden for slaves in most states, some masters did educate their slaves, and some slaves got an education in spite of their masters. Moreover, in the North, educators took great risks to teach free blacks and fugitive slaves, often facing great political resistance and personal danger to do so.Segregation in the public schools originated in the North, and then spread westward to places like California and Texas, where new kinds of people-Chinese and Mexicans, for example-were segregated away from all-white institutions. Yet even there, these racial pariahs and immigrants sometimes got an education: they were admitted to a handful of universities, and with the support of administrators and faculty members who de-emphasized the race or immigration status of these students, while at the same time embracing their intellectual merits and desire for learning. ${ }^{189}$

With these reminders that what may seem like a "radical doctrine of equality" soon comes to light as self-evident humanity, we believe that U.S. law schools must follow the example of these courageous educators and do everything they legally can to assist undocumented law school and bar applicants. ${ }^{190}$

186. Id. at 40 .

187. See id.

188. See id. at 40-51.

189. John S.W. Park, Unpublished Manuscript (unpublished manuscript) (on file with authors).

190. We want to make clear that by providing this history we are not attempting to liken the laws that created and fostered slavery and current immigration laws. The goal of this section is to show this country's legacy of professional and educational exclusion. Additionally. We make the point that it is in fact easier for today's educators to assist excluded students and graduates because it is legally permitted. 
States, and in the absence of state law, undergraduate colleges and universities, have confronted for several years now the legality of admitting, and funding undocumented students under federal immigration law and increasingly under state law. As a matter of practice, the responses have been varied across states and across college campuses. In a July 25, 2010 article in the Chronicle of Higher Education, for example, a map reveals that the responses have ranged from the most generous of both in-state tuition and state aid to undocumented students (New Mexico and Texas) ${ }^{191}$ to the most restrictive practice of banning outright their admission to higher education (Alabama and South Carolina) ${ }^{192}$ In between, several other states allow undocumented students to receive in-state tuition (Washington, California, Utah, Kansas, Nebraska, Wyoming, Illinois, and New York, Connecticut and Maryland) ${ }^{193}$ or adopt policies that result in many undocumented students paying in-state rates (Nevada and Minnesota) while others explicitly prohibit the practice (Georgia, Oklahoma, Colorado, and Arizona). ${ }^{194}$ This leaves thirty-one states without a statewide policy with regard to the admission and funding of undocumented students, and it is here where colleges and universities have stepped in to develop their own practices and policies, sometimes under the scrutiny or approval of the Board of Regents or other state official, such as the Attorney General's office. ${ }^{195}$ In fact, a 2009 survey, conducted by the American Association of Collegiate Registrars found that $54 \%$ of the colleges surveyed (613 of a total of 2,000 such institutions) knowingly accepted undocumented immigrants as students, while only $20 \%$ said they verified the immigration

191. In New Mexico, for example, undocumented students are eligible for a $\$ 5,000$ scholarship that covers their tuition and book expenses at a state school. Undocumented Students Attend Univ. New Mexico with Financial Aid, C. Blog, http://www.thecollegeblog.com/?p=30 (last visited Jan. 17, 2012).

192. States Take Varying Approaches to Immigration and Higher Education, CHRON. Higher EDUC. (July 25, 2010), http://chronicle.com/article/States-Take-VaryingApproaches/123683/.

193. Connecticut and Maryland do not appear in The Chronicle of Higher Education map since their laws were only recently adopted in May and July 2011 respectively. See, Undocumented Student Tuition: State Action, NAT'L CONF. ST. LEGISLATURES (Oct. 2011), available at http://www.ncsl.org/issues-research/education/undocumented-student-tuition-stateaction.aspx; Stephen Dockery, Connecticut Instates In-State Tuition for Illegal Immigrants, HUFFINGTON POST (July 7, 2011, 5:05 PM), http://www.huffingtonpost.com/2011/07/07/illegalimmigrant-instate n 892435.html.

194. Id.

195. See infra Part II.B. 
status of all applicants, and $31 \%$ only for the purposes of determining financial aid eligibility. ${ }^{196}$

The Chronicle of Higher Education has attributed the variation in responses to undocumented students in higher education to a lack of clear federal guidance on how states and institutions of higher learning should treat undocumented students. ${ }^{197}$ This is probably a fair characterization of federal law, although differently stated, federal law does not prohibit and, indeed, is permissive of state laws and practices that allow the admission of undocumented students and grant in-state tuition and other state aid to such students. This conclusion is consistent with the interpretation of federal law taken by U.S. Immigration and Customs Enforcement in a 2008 legal memorandum, ${ }^{198}$ as well as with state cases upholding the legality of state laws granting in-state tuition to undocumented students. ${ }^{199}$

In this section, we examine the implications of these existing state laws, practices, and legal precedents on a U.S. law school's decision to admit and financially support the education of undocumented aspiring lawyers. As a general matter, it is simple enough to suggest that law schools should feel safest in admitting and funding undocumented law students in the twelve states that explicitly grant in-state tuition or other types of equivalent benefits to undocumented students. In our analysis, however, we aim to be more nuanced. First, we wish to closely examine admitting and financing undocumented students under federal immigration law. Secondly, we want to explore the options, if any, available to law schools situated in states that explicitly bar the admission or in-state tuition of undocumented students, states that have adopted their own equivalent of anti-harboring provisions, and states where the prohibition is coming from the Board of Regents or the Attorney General's office. Thirdly, we begin the discussion of best practices in admission and funding of undocumented law students.

196. Most Colleges Knowingly Admit Illegal Immigrants as Students, Survey Finds, Chron. Higher Educ. (March 17, 2009), http://chronicle.com/article/Most-CollegesKnowingly-Admit/42575/.

197. Id.

198. Letter from Sheriff (Ret.) Jim Pendergraph, Exec. Dir., Office of State \& Local Coordination, U.S. Dep't of Homeland Sec., to M. Thomas J. Skio, Special Deputy Attorney Gen., N.C. Deputy Attorney Gen., N.C. Dep't of Justice (July 24, 2008) (discussing whether 8 U.S.C. $\S 1621$ prohibited North Carolina community colleges from enrolling undocumented students in post-secondary education courses) (on file with author).

199. See infra notes $257-70$ and accompanying text. 
A. Federal Immigration Law and the Admission of Undocumented Law Students

Under U.S. federal law, there are principally two legal concerns that law schools confront in the decision to admit and graduate undocumented law students: The first pertains to whether any of its employees could face liability from any act that supports the procurement of a U.S. law degree by a person who is not authorized to be in the United States. The second is related to law school compliance with any federal or state restriction on the conferral of any higher education benefit to undocumented students and any civil liability or other adverse consequence that could flow from that.

\section{Federal Anti-Harboring Provisions Do Not Prohibit Admitting Undocumented Students}

Section 274 of the Immigration and Nationality Act criminalizes, inter alia, illegally harboring ((a)(1)(A)(iii), and encouraging someone to, enter or reside in the U.S. ((a)(1)(A)(iv), and conspiring or aiding and abetting these crimes $((a)(1)(A)(v)$ which INA 274(a)(1)(A)(iii) provides that:

any person who knowing or in reckless disregard of the fact that an alien has come to, entered, or remains in the United States in violation of law, conceals, harbors, or shields from detection, or attempts to conceal, harbor, or shield from detection, such alien in any place, including any building or any means of transportation; shall be punished []. ${ }^{200}$

INA $\S 274(\mathrm{a})(1)(\mathrm{A})(\mathrm{iv})$ provides "any person who encourages or induces an alien to come to, enter, or reside in the United States, knowing or in reckless disregard of the fact that such coming to, entry, or residence is or will be in violation of law." ${ }^{201}$ Harboring, encouraging, and aiding and abetting violations are punished with up to five years of incarceration, unless done for commercial advantage or financial gain. ${ }^{202}$

The question that arises from these provisions is what would constitute harboring or encouraging the unauthorized residence in the United States as it pertains to admitting and graduating undocumented students by U.S. law

200. Immigration and Nationality Act $\S 274,8$ U.S.C. $\S 1324$ (2006).

201. 8 U.S.C. $\$ 1324($ a)(1)(A)(iv) (2006).

202. Ira J. Kurzban, Criminalizing Immigration Law, in 42ND ANNUAL IMMIGRATION \& NAturalization InstituTE, at 321, 362 (PLI Corporate Law \& Practice, Course Handbook Ser. No. 1768, 2009). For a useful historical discussion of the anti-harboring provisions, see William G. Phelps, Annotation, Validity, Construction, and Application of $\$ 274($ a) $(1)($ A) (iii) of the Immigration and Nationality Act (8 U.S.C.A \$ 1324(a)(1)(A)(iii), Making it Unlawful to Harbor or Conceal Illegal Alien, 137 A.L.R. FED. 255 \& 2 (1997). 
schools. Given that the mens rea of either crime requires knowledge or reckless disregard of a persons' immigration status, one potential legal solution could be for law schools to adopt the equivalent of a "Don't Ask, Don't Tell" policy with regard to a student's immigration status. From a practical stand-point, such a policy under current law could work. Unlike employers, ${ }^{203}$ institutions of higher learning are not required by federal law to track their students' immigration status, except with respect to foreign students who hold nonimmigrant visas ${ }^{204}$ and for purposes of helping students apply for financial aid. Thus, law schools could simply avoid any question in the admission process that could disclose to the school a student's immigration status, including requiring a social security number. In fact, as we note in Part $\mathrm{C}$ of this section, as a best practice, law schools should not mandate student disclosure of their immigration status for admission purposes, save in the few instances that immigration status is relevant, such as to determine financial aid eligibility or to comply with the SEVIS reporting requirements, which only apply to documented foreign students holding a student visa.

However, it is inevitable and for many reasons desirable for undocumented law students to voluntarily self-disclose their immigration status in order to seek and receive the support they need from their law school in order to participate as fully as possible in their educational experience and to integrate as well as possible as law graduates and lawyers. Indeed, we are concerned that a "Don't Ask, Don't Tell" practice would discourage or make impossible some of the best practices that we recommend in this paper. These practices would require greater involvement in the success of these undocumented students beyond their simple admission into the law school. Despite recent high-profile stories in the media of exceptional, high-achieving undocumented students who have risen to the top against all odds, ${ }^{205}$ thoughtful studies provide a contrast by revealing the more typical experiences of the large majority of undocumented students. ${ }^{206}$ Considerable debate remains around how much school success is a matter of agency (individual merit and internal qualities) or structure (external factors, including teacher and peer support); however, research shows that for many students, including undocumented students,

203. See, e.g., Kati L. Griffith, Discovering "Immployment" Law: The Constitutionality of Subfederal Immigration Regulation at Work, 29 YALE L. \& POL'Y REV. 389 (2011).

204. See infra note 213 and accompanying text.

205. See, e.g., Maggie Jones, Coming Out Illegal, N.Y. Times MaG., Oct. 24, 2010, at MM36, available at http://www.nytimes.com/2010/10/24/magazine/24DreamTeam-t.html.

206. See, e.g., Roberto G. Gonzales, On the Wrong Side of the Tracks: Understanding the Effects of School Structure and Social Capital in the Educational Pursuits of Undocumented Immigrant Students, 85 PEABODY J. OF EDUC., no. 4, 2010 at 469. 
their success is largely determined by their ability to form positive relationships with school personnel and high-achieving peers, furthermore, the formation of these relationships are mediated by school structures that position students within the school system. ${ }^{207}$ We advocate, therefore, as a best practice, that law schools create a structure that encourages undocumented students to seek out the mentorship and relationships necessary to ensure their success. As such, in this paper, we take up the more difficult question of how and whether the anti-harboring provisions may be triggered when the undocumented status of a law student is known to some of the employees at the law school, whether as a result of a student who chooses to self-disclose to an individual faculty member or because the law school encourages self-disclosure for the purposes of lending support to the students. This may include making available to these students publically and/or privately available financial support, opportunities for experiential educational learning, including clinics and externships while in law school, support with immigration legalization through legal clinics, and even identifying career opportunities post-graduation, including volunteer work opportunities within the United States, or paid legal jobs beyond U.S. borders.

In answering this question, we first acknowledge that it requires not only a purely legal analysis, but that it is also involves assessing the political landscape with regard to the exercise of prosecutorial discretion by federal immigration agencies. Historically, criminal prosecutions of any type for purposes of internal immigration enforcement have been rare. ${ }^{208}$ Starting under President George W. Bush's administration, however, and continuing through President Barack Obama's, federal criminal immigration prosecutions have skyrocketed, increasing not only the number of those who are targeted for prosecution, but also expanding the scope of prosecution to include both immigrants who broke the law to be in the U.S. and individuals who may have facilitated another's illegal entry or continuing presence through the anti-harboring provisions. ${ }^{209}$ To date, the new targets have solely been employers ${ }^{210}$ and not institutions of higher learning. ${ }^{211}$ Indeed, while not applied consistently, the current practice is to

207. Id. at 472 .

208. See Kurzban, supra note 202, at 361 (citing to 52 FR 16217) (May 1, 1987).

209. Id.

210. Mira Mdivani, Employer Prosecutions Triggered by Allegations of Immigration Law Violations: Legitimate Law Enforcement or Misguided Policy Tool?, 79 UMKC L. REV. 827, 835-45 (2011).

211. A search in allnews related to harboring immigration charges and prosecutions in the last five years revealed only a handful of cases involving higher institutions, namely pertaining 
defer the removal of undocumented students caught up in immigration enforcement (at least those without a criminal history) until Congress resolves their fate through legislation. ${ }^{212}$ There are sound legal and policy reasons for this choice. For one, in 1986, Congress expressly imposed civil and criminal sanctions for the unauthorized employment of immigrant workers. ${ }^{213}$ In stark contrast, when Congress legislated in the areas of higher education, it adopted a permissive policy toward allowing each state to determine issues of residency for purposes of admission and the conferral of state financial aid to undocumented students attending institutions of higher learning, restricting solely the eligibility of federal financial aid and federal student loans. ${ }^{214}$ Thus, federal immigration law does not proscribe the education of undocumented students beyond $\mathrm{K}-12$; and indeed, if it did, it might even trigger a Plyler-like equal protection challenge or a federalism claim by states who legitimately view this an educational policy matter, not an immigration question.

Still, even if today institutions of higher learning are not the targets of federal prosecutions and are unlikely to become the targets of federal prosecutions for the reasons given, the question remains as to whether, as a matter of law, federal prosecutors might have reasonable grounds to charge a law school employee under federal anti-harboring provisions for their support of undocumented students. That answer is likely to be "no" in most instances, but it could depend on the circumstances. To date, there does not appear to be a case on point. Tens of thousands of undocumented students attend college each year, but no university employee has ever been prosecuted or convicted with federal anti-harboring provisions for simply doing their job educating undocumented students. ${ }^{215}$ One recent story did report that a university official was criminally charged with harboring, but that case involved his false reporting of information involving foreign students into the SEVIS database for purposes of protecting those students' immigration status. ${ }^{216}$ Other cases involving criminal immigration charges

to immigration fraud where those institutions were falsely procuring student visas on behalf of foreign students.

212. See, e.g., Asian Law Caucus et al., Education Not Deportation: A Guide for Undocumented Youth in Removal Proceedings 9, http://www.e4fc.org/images/E4FC DeportationGuide.pdf (last visited Mar. 24, 2012).

213. Griffith, supra note 203, at 396-97.

214. See supra Part II.B.

215. A search of federal cases and newspaper stories in the last five years did not yield a single case involving the prosecution of a university employee for harboring.

216. Eric Frazier, Ex-UNCC Staffer Faces Visa Charges; Acted "out of concern" for Students, CHARLOTTE OBSERVER (July 15, 2011), http://www.charlotteobserver.com/2011/07/ 14/2455234/ex-uncc-staffer-is-tied-to-visa.html. 
against institutions of higher learning pertain to fraud, namely when the institution falsely used student visas to help foreign residents enter the country. ${ }^{217}$ As these cases exemplify, it is fair to say that a law school employee could go too far in his or her support of undocumented law students (or foreign students). Still, the question is, what is too far? A look at all cases and charges involving harboring to date can start to provide some answers.

As a general matter, federal prosecutions under the anti-harboring provisions have required that every defendant commit an affirmative act that substantially facilitates their entry or stay in the United States, and not solely the mens rea of knowing or recklessly disregarding that someone is unlawfully present in the United States. ${ }^{218}$ The substantial facilitation appears to be a matter of degree. A common type of case giving rise to charges and/or prosecutions for harboring, thus, might involve defendants who have also participated in the smuggling or trafficking of the immigrants or those who have helped a group of unrelated undocumented immigrants by procuring false documents and jobs, arranging sham marriages, and providing shelter. ${ }^{219}$ In such cases, it is not necessary for the prosecution to prove that defendant took each of the steps to aid the immigration with the intent to help the immigrant avoid detection by the immigration authorities. ${ }^{220}$ Proving financial gain on the part of the defendant is also not an element of the crime. ${ }^{221}$ Harboring convictions have also included defendants, including employers, who have either procured the false documents on behalf of the worker or provided transportation and shelter or who have affirmatively attempted to hide and conceal undocumented immigrants from immigration enforcement, or who have seized the opportunity to evade other tax and labor laws by hiring undocumented

217. Id.

218. See, e.g., United States v. De Jesus-Batres, 410 F.3d 154, 160 (5th Cir. 2005) (establishing harboring requires that defendant's conduct tended to substantially facilitate the immigrant remaining in the U.S.).

219. See, e.g., id.; United States v. Bonetti, 277 F.3d 441 (4th Cir. 2002); United States v. Sanchez, 927 F.2d 376 (8th Cir. 1991); United States v. Acosta De Evans, 531 F.2d 428 (9th Cir. 1976), cert. denied, 429 U.S. 836 (1976); United States v. Lopez, 521 F.2d 437 (2d Cir. 1975), cert. denied, 423 U.S. 995 (1975); Susnjar v. United States, 27 F.2d 223 (6th Cir. 1928).

220. See United States v. Aguilar, 883 F.2d 662 (9th Cir. 1989), cert. denied, 498 U.S. 1046 and United States v. Acosta de Evans, 531 F.2d at 430 (holding that the word "harbor" means "to afford shelter to" and does not require the intent to avoid detection). But see United States v. Gelevin-Ramales, 458 F. Supp. $2 d 409$ (E.D. Ky. 2006) (harboring does require proof that the defendant sought to assist the person in an attempt to evade and avoid detection).

221. See, e.g., United States v. De Jesus-Batres, 410 F.3d 154, 160 (5th Cir. 2005). 
workers. $^{222}$ More recent prosecutions against employers reveal similar patterns of conduct. Consider the guilty plea for charges that included harboring, by Agriprocessors Chief Executive Officer Sholom Rubashkin and several other managers, who not only helped procure false documents on behalf of workers but also engaged in additional violations involving financial fraud and child labor laws. ${ }^{223}$ Similarly, convictions for encouraging immigrants to reside in the U.S. where such residence violates the law have included defendants who took substantial steps to help the immigrant violate the law, such as selling them fraudulent work authorizations or other false U.S. documentation. ${ }^{224}$

As a general matter, moreover, it is important to note that a "passive participant" in someone's unauthorized stay in the United States, even with knowledge, has not resulted in charges or prosecution. Consider, for example, that normally it has not been the practice to prosecute employers for the mere employment of undocumented workers, even with knowledge of the worker's lack of work authorization. ${ }^{225}$ However, there have been some exceptions. In 1986, when Congress adopted the Immigration Reform and Control Act, in fact, it also eliminated the exception that employment is not harboring, although the INS, in comments to the implementing legislation, also made it clear that harboring would not apply in cases involving solely employment. ${ }^{226}$ In most cases, then, "mere employment," has become a defense to the charge of harboring. Despite this, some courts, albeit only a few, have held that mere employment does constitute harboring. ${ }^{227}$ In another case, a defendant did not commit harboring even though he told an immigrant to keep a low profile, and that it was good that

222. United States v. Varkonyi, 645 F.2d 453 (5th Cir. 2011); United States v. Shum, 496 F.3d 390 (5th Cir. 2007); United States v. Zheng, 306 F.3d 1080 (11 th Cir. 2002); United States v. Rubio-Gonzalez, 674 F.2d 1067 (5th Cir. 1982); United States v. Cantu, 557 F.2d 1173 (5th Cir. 1977).

223. Mdivani, supra note 210 , at 844 . Similarly, the guilty plea for harboring of the owner of S\&S bakery in 2010 involved the falsification of social security numbers and the provision of fraudulent immigration documents to the workers. $I d$.

224. United States v. Ndiaye, 434 F.3d 1270, 1296-98 (11th Cir. 2006) (fraudulently obtaining a social security card); United States v. Oloyede, 982 F.2d 133 (4th Cir. 1992) (lawyer representing persons at INS who was a co-conspirator to person who sold the clients their fake social security cards).

225. United States v. Moreno-Duque, 718 F. Supp. 254 (D. Vt. 1989).

226. Ira J. Kurzban, Criminalizing Immigration Law, 1768 PRACTICING L. INST. 321, 363 (2009) (citing 57 FR 16,217 (May 1, 1987)).

227. United States v. Kim, 193 F.3d 567, 572-74 (2d Cir. 1999). On the facts of Kim, however, the employer took steps to help the worker remain in the United States without authorization. Another court refused to find reversible error for a district judge to refuse to give a "mere employment" jury instruction to harboring and smuggling charges. United States v. Khanani, 502 F.3d 1281, 1285-89 (11th Cir. 2007). 
the immigrant lived at an address different than the one on file with immigration. ${ }^{228}$ Similarly, in 2012 the U.S. Court of Appeals for the Third Circuit held that mere housing does not constitute harboring, even if the landlord in question sought out undocumented potential tenants because they were less likely to complain about conditions. ${ }^{229}$ This decision offers further assurance to law schools that provide university housing to undocumented students.

Based on an examination of these cases, we conclude that admission and education of undocumented law students does not constitute harboring, particularly when the decision to admit did not require disclosure of applicants' immigration status. Would the analysis change, however, if the unauthorized legal status of a student becomes known to the law school, such as when a student voluntarily discloses the information to a faculty or school administrator? The answer may depend on the circumstances of the disclosure and the conduct of the law school employee; thus, we take up in this section some possible scenarios of how this self-disclosure could occur. As a general matter, under all circumstances, we maintain that neither the law school nor the individual staff nor faculty member is required to report the student to the immigration authorities nor to dismiss that student from the law school. The federal anti-harboring provisions do not create an affirmative duty to report immigration violators. Under federal immigration law, mandatory reporting requirements of the status of undocumented persons do exist, but only in narrowly defined circumstances. Namely, in 1996, when Congress adopted the Personal Responsibility and Work Opportunity Reconciliation Act of 1996 (PRWORA) to tighten immigrants' eligibility for public benefits, it also delegated to states the administration of public benefits programs, including the requirement to verify an applicant's immigration status and mandatory reporting requirements to immigration authorities for three federal programs (social security income, public housing, and Temporary Assistance for Needy Families) when the agency knows that the applicant is not lawfully present in the United States. ${ }^{230}$ In the context of higher education, mandatory-reporting requirements as to student immigration violations also exist, but only with respect to SEVIS

228. United States v. Ozcelik, 527 F.3d 88 (3d Cir. 2008), cert. denied, 555 U.S. 1153 (2009).

229. See Delrio-Mocci v. Connolly Prop. Inc. et al., No. 09-4541, 2012 WL 592917, at *4 (3d Cir. Feb. 24, 2012).

230. Personal Responsibility and Work Opportunity and Reconciliation Act of $1996 \S 404$, Pub. L. No. 104-193, 110 Stat. 2105, 2267 (1996) (codified as amended at 8 U.S.C. $\$ 1614$ (1996) and 42 U.S.C. $\S 611 \mathrm{a}$ (1996)), amended by Balanced Budget Act of 1997, §§564, 5581(a). 
violators; SEVIS applies solely to students who hold a student visa. ${ }^{231}$ Even under IRCA, an employer's obligation to verify immigration status does not obligate the employer to report the worker to the immigration authorities, although in that case, an employer would have to dismiss an employee whom he knows is working without authorization or face liability. In contrast, law schools would not have to dismiss a student who is undocumented. Unlike IRCA, no federal law exists that proscribes the education of undocumented students. And as already noted, even when Congress legislated in 1996 to restrict the availability of financial aid to certain immigrant students who were not at least lawful permanent residents or naturalized U.S. citizens, it reserved for states the power to decide whether it would educate undocumented students and even also whether it would confer state financial aid benefits in the education to these students, requiring only that states affirmatively legislate to do so post-1996. ${ }^{232}$ Indeed, at least 13 states have moved to do just that by adopting laws that grant undocumented students in their states in-state tuition benefits. ${ }^{233}$ These laws and the cases that uphold their legality are taken up in the next section on financial aid.

Additional protections for student disclosures apply in the law school context. For example, the Family Educational Rights and Privacy Act mandates confidentiality of "education records." 234 Educational institutions are permitted to release information in defined contexts. For example, schools may disclose, without consent, a student's name and contact

231. See Aliens who may be Unlawfully Present in the United States and Their Access to Public Post-Secondary Education Institutions, U.S. IMMIGRATION \& CUSTOMS ENFORCEMENT OFFICE 1 (July 6, 2010), http://iwp.legalmomentum.org/reference/additional-materials/publicbenefits/education-financial-aid/7\%20SEVP $\% 20$ Info $\% 20$ Undocumented $\% 20$ Student $\% 2007$ $\% 2002 \% 2010$.pdf/view? searchterm=Post+secondary+ ("Pursuant to 8 C.F.R. $\S$ 214.3(g)(3)(ii)(A), schools are required to report to the government within 21 days when a student or exchange visitor in $\mathrm{F}, \mathrm{M}$ or $\mathrm{J}$ nonimmigrant status fails to maintain his or her status to complete his or her program. Other than these reporting requirements for nonimmigrant students and exchange visitors in F, M, or J status who have registered with SEVP and are in SEVIS, no other provisions exist that require schools to report students who are unlawfully present to the government"); see also Policy Guidance for: SEVIS Users at SEVP-Certified Schools, U.S. IMMIGRATION \& CUSTOMS ENFORCEMENT OFFICE 2 (Oct. 27, 2010), http://www.nafsa.org/ uploadedFiles/SEVPPolicyGuidance1004_07\%20DSOReporting.pdf ("Federal law and regulations require DSOs of SEVP-certified schools to update and maintain the SEVIS records of $\mathrm{F}$ and $\mathrm{M}$ nonimmigrants.").

232. See supra Part II.B.

233. See Michael Olivas, No Undocumented Child Left Behind: Plyler v. Doe And THE EDUCATION OF UNDOCUMENTED SCHOOLCHILDREN 66-67 (2012) (Texas, California, Utah, New York, Washington, Oklahoma, Illinois, Kansas, New Mexico, Nebraska, Wisconsin, Maryland, Connecticut). Wisconsin has since rescinded this policy. See id.at 66.

234. 20 U.S.C. $\S 1232 \mathrm{~g}$ (2006). 
information and other details, including, most importantly for undocumented students, the student's place of birth. ${ }^{235}$ Students do, however, have "a reasonable amount of time," to request that the school not include information such as place of birth in their "directory information." "236 Schools may also release education records without the student's consent in various additional circumstances such as health and safety emergencies, ${ }^{237}$ as required by judicial order or law enforcement, ${ }^{238}$ and as needed for financial aid purposes. ${ }^{239}$ Undocumented status is not an exception to the FERPA confidentiality requirements.

When the interaction between the law school and university and an undocumented law student amounts to a patient or client relationship, even greater protections will apply. The regulations implementing FERPA recognize that records "[m]ade or maintained by a physician, psychiatrist, psychologist, or other recognized professional or paraprofessional acting in his or her professional capacity or assisting in a paraprofessional capacity," 240 "[m]ade, maintained, or used only in connection with treatment of the student," 241 and "[d]isclosed only to individuals providing the treatment," 242 do not constitute education records. ${ }^{243}$ Instead, these records gain the greater protection afforded by codes of professional ethics and evidentiary privilege rules.

In the law school context, the particular likelihood is that undocumented students will interact with administrators, faculty, or staff who are also lawyers or paralegals, in which case the students' self-disclosure may amount to a client communication, such that a professional ethical duty of confidentiality would be breached were the law school employee to share the student's disclosure. This would most clearly be the case were an undocumented law student to seek out an immigration law or clinical

235. Id. $\S 1232 \mathrm{~g}(\mathrm{a})(5)(\mathrm{A}),(\mathrm{b})(1)$.

236. Id. $\S 1232 \mathrm{~g}(\mathrm{a})(5)(\mathrm{B})$.

237. Id. $\S 1232 \mathrm{~g}(\mathrm{~b})(1)(\mathrm{I})$.

238. Id. $\S 1232 \mathrm{~g}(\mathrm{~b})(1)(\mathrm{E})$. Note that this exception does not mean that law schools must report their students to the authorities for violations of the law; they simply must provide records when required by law enforcement or the judiciary.

239. Id. $\S 1232 \mathrm{~g}(\mathrm{~b})(1)(\mathrm{D})$.

240. Dep't. of Educ. Family Educational Rights and Privacy Rule, 34 C.F.R. § 99.3(4)(i) (2011)

241. Id. $\$ 99.3(4)($ ii)

242. $I d . \S 99.3(4)($ iii).

243. Id. $\S 99.3(4)$. In the regulations, these records are referred to as "treatment records," because the regulation drafters appear to have been focused on medical and psychological contexts. However, the general language "or other recognized professional or paraprofessional acting in his or her professional capacity or assisting in a paraprofessional capacity" indicates that lawyers and legal case files were intended to be included in this exclusion from the definition of education records. $I d$. $\S 99.3(4)(\mathrm{i})$. 
professor or paralegal for assistance, including on possibilities of seeking legalization in the United States or lawful gainful employment after graduation, or even the legality of seeking admission to the bar. According to the Third Restatement of the Law Governing Lawyers, a lawyer/client relationship arises when:

A person manifests to a lawyer the person's intent that the lawyer provide legal services for the person; and either (a) the lawyer manifests to the person consent to do so; or (b) the lawyer fails to manifest lack of consent to do so, and the lawyer knows or reasonably should know that the person reasonably relies on the lawyer to provide the services. ${ }^{244}$

Although this inquiry will differ according to the jurisdiction in which the law school sits, the generic answer seems to be that this standard is relatively easily triggered, ${ }^{245}$ meaning that licensed attorneys and practicing paralegals in the law school setting who field questions from undocumented students may have formed a professional relationship. Even when no relationship is formed, the duty of confidentiality still attaches to the information gathered in an initial consultation. ${ }^{246}$

All of these protections create an environment within which law school administrators and faculty can and should engage undocumented students to provide advice on common and recurring issues that these law students will confront, including their eligibility for federal, public, and private sources of financial aid, or their ability to complete unremunerated externships, internships or legal clinics while in law school. Giving any of this advice would not constitute harboring because it is not intended to help the student engage in the further violation of the immigration laws. Law schools and their employees need to be careful, however, not to advise students in such a way that seems to be helping them to avoid detection or to further violate the immigration laws. For example, a counselor or faculty advisor might be tempted, as was the defendant in the case discussed above, to advise a student to move if they believe that the immigration authorities have become aware of them. Although the defendant in that case was not convicted of harboring, this type of advice comes too close to harboringand, for lawyers - an ethical line. Similarly, assisting any undocumented law student to procure false documents, or knowingly facilitating

244. RESTATEMENT (THIRD) OF THE LAW GOVERNING LAWYERS $§ 14$ (2011).

245. See, e.g., Catherine J. Lanctot, Attorney-Client Relationships in Cyber-Space: The Peril and the Promise, 49 DUKE L.J. 147, 170 (1998) ("a careful examination of the law suggests that the attorney-client relationship cannot easily be disclaimed").

246. See ABA Comm. on Ethics \& Prof'1 Responsibility, Formal Op. 90-358 (1990) (discussing the duty of confidentiality for information gained in preliminary consultations). 
unauthorized employment, or even knowingly providing a student with shelter could very well cross that line as well. For the reasons explored in Part II.A.2 below, however, we do not consider helping undocumented students tap into either public or private resources as a way of financing their legal education to constitute harboring, so long as these are done within the bounds of what is permitted under federal law.

\section{Legally Funding the Education of Undocumented Law Students}

The second major legal issue that law schools must confront in the admissions process is how to lend support to the undocumented students they admit to finance their legal education through private funds, or even public funds when these are available without violating federal law. This point is crucial, given the rise in cost of legal education ${ }^{247}$ and the financial situation of most undocumented students who are already low-income, and who must also face employment and financial assistance restrictions that impede their education at institutions of higher learning. ${ }^{248}$ A simple initial step that law schools should undertake is to be well informed of the nature and scope of federal restrictions on financial aid to undocumented students. There has been some misapprehension and misinformation around the legality, for instance, of states' granting in-state tuition to undocumented students. ${ }^{249}$ As this section explains, these conferrals of in-state tuition status are legal. Thus, at a minimum, law schools should and must provide opportunities that guarantee meaningful access to undocumented students of that financial assistance that is legitimately available to them. Unfortunately, many if not most undocumented students possess very little information or are afraid of the immigration consequences if they apply for that aid; and, thus, underutilize financial assistance, whether private or public, that is legitimately available to them. ${ }^{250}$ Another persistent barrier, unfortunately, falls on the schools themselves when employees lack the

247. Comm'N ON the ImPaCt of the ECon. Crises on the Prof'L and Legal NeEds, Am. Bar Ass'N, The Value Proposition of AtTending LaW Schools, http://www.americanbar.org/content/dam/aba/migrated/lsd/legaled/value.authcheckdam.pdf.

248. LISA D. GARCIA \& WILLIAM G. TIERNEY, Undocumented Immigrants in Higher Education: A Preliminary Analysis, 113 TCHRS. C. REC. 2739 (2011).

249. See Thomas R. Ruge \& Angela D. Iza, Higher Education for Undocumented Students: The Case for Open Admission and In-State Tuition Rates for Students Without Lawful Immigration Status, 15 IND. INT'L \& COMP. L. REV. 257, 264-66 (2005).

250. GARCIA \& TIERNEY, supra note 248, at 10-13; see also H. Kenny Nienhusser \& Kevin J. Dougherty, Implementation of College In-State Tuition for Undocumented Immigrants in New York, NYLARNET PAPER, Spring 2010, at 1, available at http://www.nylarnet.org/reports/ imm_in $\% 20$ state $\% 20$ tuition.pdf. 
knowledge or are sometimes insensitive or even hostile to undocumented students. ${ }^{251}$ Therefore, in Part III, we take up some best practices aimed simply at improving student access to financial assistance in law schools that is already available to them. In short, we recommend that law schools take a more proactive role in helping undocumented students identify, procure and use other private sources of financial aid to fund their legal education. The question here becomes what are the federal law restrictions on how much law schools can do to assist undocumented law students in funding their legal education.

There are two provisions under U.S. federal law relevant to the issue of funding the higher education of undocumented students. Since 1996, Section 505 of the Illegal Immigrant Reform and Immigrant Responsibility Act has prescribed that ${ }^{252}$

an alien who is not lawfully present in the United States shall not be eligible on the basis of residence within a State (or a political subdivision) for any postsecondary education benefit unless a citizen or national of the United States is eligible for such a benefit (in no less an amount, duration, and scope) without regard to whether the citizen or national is such a resident. ${ }^{253}$

Further, the Personal Responsibility and Work Opportunity Reconciliation Act (PRWORA) denies post-secondary monetary assistance to undocumented immigrants; and any state wishing to make an undocumented immigrant eligible for any state or local public benefit for which the alien would otherwise be ineligible for under PRWORA must enact affirmative legislation granting such benefit. ${ }^{254}$ Despite these restrictions, since 2001 thirteen states (California, Connecticut, Illinois, Kansas, Maryland, Nebraska, New Mexico, New York, Texas, Utah, Washington, and Wisconsin) have passed laws that permit certain undocumented students to pay in-state tuition, ${ }^{255}$ and three of these states, California, New Mexico and Texas, even allow eligible undocumented students the ability to partake in its state financial aid programs, although it is not clear these are available to fund post-graduate programs. ${ }^{256}$ In 2008 ,

251. Nienhusser \& Dougherty, supra note 250 , at 1.

252. Illegal Immigration Reform and Immigrant Responsibility Act of 1996 § 505, 8 U.S.C. $\S 1623(1996)$.

253. Id.

254. 8 U.S.C. $\S 1621$.

255. Michael Olivas, Compilation: State Legislation Allowing Undocumented College Students to Establish Residency, BENDER'S IMMIGR. BULL. (Jan. 2 2010), http://www.law.uh.edu/ihelg/documents/1-1-10bibfinal421_01_2010.pdf.

256. See, e.g., California Dream Act of 2011, A.B. 130, 2011-2012 Session (Ca. 2011) (making undocumented California residents eligible to receive scholarships "derived from 
Oklahoma amended its law, leaving the authority to grant in-state tuition rates to undocumented students to the Oklahoma Board of Regents, which the Board of Regents still allows. ${ }^{257}$ In the remaining twelve state laws, in general eligible undocumented students must live in state and have attended high school for a specified period of time (1-3) years, and graduate from a state high school or receive their GED.

There has been disagreement and litigation over whether Section 505 of the IIRIRA prohibits the granting of in-state tuition; ${ }^{258}$ however, recent court rulings and federal agency guidance affirm that states opting to grant in-state tuition and financial aid to undocumented students stand on firm legal ground in interpreting the "unless clause" in Section 505 as codifying the principle that determining residency in a state is a state matter. In 2007 and 2008, two cases, Day v. Bond ${ }^{259}$ and Martinez v. Regents of Univ. of Cal. ${ }^{260}$ brought to appellate courts in Kansas and California respectively, challenged the granting of in-state tuition benefits to undocumented students. Plaintiffs in both cases, out-of-state students charged out-of-state tuition in schools of higher learning in those states, argued that the granting of in-state tuition to undocumented students violated federal immigration law and the Equal Protection Clause. Both cases were originally dismissed for lack of standing on the grounds that plaintiffs failed to prove that the law injured them personally. ${ }^{261}$ Only Kansas' dismissal, however, was upheld by the Tenth Circuit Court of Appeals, ${ }^{262}$ a ruling that the Supreme Court declined to review. ${ }^{263}$ The Kansas district court in its ruling also considered the effect of the two 1996 federal laws (IIRIRA and PRWORA) and affirmed states' right to deny or accord in-state tuition to undocumented

nonstate funds."). On October 9, 2011, California also passed into law A.B. 131, which made public scholarship monies available to undocumented students. Patrick McGreevy \& Anthony York, Brown signs California Dream Act funding bill, L.A. TIMEs, Oct. 9, 2011, at A1, available at http:/articles.latimes.com/2011/oct/09/local/la-me-brown-dream-act-20111009; see also Michael A. Olivas, Undocumented College Students, Taxation, and Financial Aid: A Technical Note, 32 REV. HigHER EDUC. 407, 412 for a discussion of the tax complexities faced by undocumented students applying for financial aid in Texas.

257. Undocumented Student Tuition: Overview, NAT'L CONF. ST. LEGISLATUREs (October 2011), http://www.ncsl.org/issues-research/education/undocumented-student-tuition-overview. aspx.

258. See Jody Feder, Cong. Research Serv., RS 22500, UnAUthorized Alien Students, Higher Education, and In-State Tuition Rates: A Legal Analysis (2010), available at http://www.policyarchive.org/handle/10207/bitstreams/19519_Previous_Version 2010-01-13.pdf.

259. 500 F.3d 1127 (10th Cir. 2007).

260. 83 Cal. Rptr. 3d 518 (Cal. Ct. App. 2008), rev'd, 241 P.3d 855 (Cal. 2010).

261. Day, 500 F.3d at 1131; Martinez, 83 Cal. Rptr. 3d at 527.

262. Day, 500 F.3d at 1130 .

263. Day v. Bond, 554 U.S. 918 (2008). 
students. ${ }^{264}$ In the California case, while a California Court of Appeals initially reversed the dismissal and held that the California statute violated federal immigration law, ${ }^{265}$ the California Supreme Court upheld the provisions of the California state statute according undocumented students and others in-state resident tuition status on the basis of prior attendance and graduation from a California high school. ${ }^{266}$ The plaintiffs alleged that federal law, IIRIRA, preempted the California in-state tuition provisions. ${ }^{267}$ Specifically, the plaintiff argued that the California statute "makes an unlawful alien eligible for a benefit (in-state tuition) on the basis of residence without making a citizen eligible for the same benefit." ${ }^{268}$ The California Supreme Court held:

Because the exemption is given to all who have attended high school in California for at least three years (and meet the other requirements), and not all who have done so qualify as California residents for purposes of in-state tuition, and further because not all unlawful aliens who would qualify as residents but for their unlawful status are eligible for the exemption, we conclude the exemption is not based on residence in California. Rather, it is based on other criteria. ${ }^{269}$

Then on June 6, 2011, the U.S. Supreme Court declined to review the holding. ${ }^{270}$

In 2008, the Department of Homeland Security, though the USCIS, issued a letter in response to a request from education officials in North Carolina on the question of whether federal legislation proscribed states from adopting in-state tuition laws benefiting undocumented students. ${ }^{271}$ This letter confirmed the rulings by the Kansas and California courts in stating that determining state status and conferring state residency status remained a state matter. ${ }^{272}$

Undocumented student eligibility for in-state tuition is a significant financial help but, given their general ineligibility to work and for federal

264. See generally Day v. Sebelius, 376 F. Supp. 2 d 1022 (D. Kansas 2005).

265. Martinez, 83 Cal. Rptr. 3d at 543.

266. Martinez v. Regents of Univ. of Cal., 241 P.3d 855, 870 (Cal. 2010).

267. Id. at 860 .

268. Id. at 862 .

269. Id. at 860 .

270. In-State Tuition and Unauthorized Immigrant Students, NAT'L CONF. ST. LEGISLATURES, http://www.ncsl.org/default.aspx?tabid=13100 (July 8, 2011).

271. Letter from Jim Pendergraph, Exec. Dir., Office of State and Local Coordination, to Thomas J. Ziko, Special Deputy Attorney Gen., N.C. Dep't of Justice (July 9, 2008), available at http://www.nilc.org/document.html?id=86.

272. Id. 
and state financial aid, economic barriers to finance law school remain. ${ }^{273}$ Of course, federal law does not preclude undocumented students from relying on private funds to finance their legal education and states can also choose to affirmatively legislate to finance the education of undocumented students through public state funds. ${ }^{274}$ This raises the question as to whether law schools may be held liable for the co-mingling of private foundation funds with law school funds, which may raise an argument as to whether the law school is providing federal financial aid to undocumented students. If the funds are totally separate from law school funds, then this should not raise a problem. Thus, the issue remains how best law schools can support the identification and access of these funds for undocumented students without violating the federal law restrictions against financial aid for undocumented students. Some private organizations may, however, offer financial assistance to undocumented students unconnected to the university.

\section{What Happens if My Law School is in a State that bars Undocumented Students from access or funding to higher education?}

Answering this question requires an examination of the existing state law that would govern the terms of access to higher education by undocumented students and an assessment of the legality of these laws. With regard to law schools in states where there are no existing policies governing either the admission or a grant of in-state tuition for undocumented students, we maintain that under federal law they are free to adopt permissive policies with regard to the admission and the charging of in-state tuition fees based on the same legal reasoning provided in Part II.A, provided these policies do not violate other existing state laws, such as conflicts with existing residency policies.

Only three states (Alabama, South Carolina and Georgia) ban the admission of some or all undocumented students outright, ${ }^{275}$ while only four

273. See Lindsay Perez Huber \& Maria C. Malagon, Silenced Struggles: The Experiences of Latina and Latino Undocumented College Students in California, 7 NEV. L.J. 841, 846 (2007).

274. Section 1621 (d) of the IIRIRA reads:

A State may provide that an alien who is not lawfully present in the United States is eligible for any State or local public benefit for which such alien would otherwise be ineligible under subsection (a) of this section only through the enactment of a State law after August 22, 1996, which affirmatively provides for such eligibility.

275. See Perla Treviso, Georgia Bill Banning Illegal Immigrants from Public Colleges Advances, TIMES FreE PRESs (Mar. 5, 2012), http://timesfreepress.com/news/2012/mar/05/ 
(Georgia, Oklahoma, Colorado, and Arizona) deny in-state tuition to undocumented students. ${ }^{276}$ In other states, restrictive policies toward the admission or conferral of in-state tuition are adopted as university policies, sometimes mandated by the Board of Regents or influenced by other state officials. For example, in 2002, Virginia public institutions of higher education adopted a policy to deny admission to undocumented students in response to a memorandum from the Virginia Attorney General that asserted that unauthorized immigrants should not be admitted to Virginia's public colleges and universities and that, as a matter of law, Virginia had wide discretion to decide these matters. ${ }^{277}$ Also, the North Carolina Community College System has changed its admission policy for undocumented students five times; most recently in 2009 when those who have graduated from a North Carolina high school and who are able to pay out-of-state tuition, are allowed to enroll in the North Carolina Community College System. ${ }^{278}$ In October 2010, Georgia's State Board of Regents passed new rules regulating the admission of undocumented students requiring all 35 institutions of higher learning in the state to verify "lawful presence" for students seeking in-state tuition and prohibiting the admission of undocumented students. ${ }^{279}$

One question is whether it is constitutionally permissible for a state to prohibit unauthorized immigrants from attending state colleges and universities, let alone receive in-state tuition. So far, only one federal court has squarely addressed the question, based principally on the Supremacy and Due Process Clauses of the U.S. Constitution. ${ }^{280}$ In Equal Access Education v. Merten, plaintiffs seeking access to Virginia's institutions of higher learning alleged that the universities were engaging in the impermissible regulation of immigration by trampling a field already

georgia-bill-banning-illegal-immigrants-public-col/ (noting that Alabama has banned undocumented students from two-year colleges, Georgia has banned them from colleges that have previously exceeded their entering class capacity, and South Carolina has banned all undocumented students from all institutions of higher education).

276. See supra notes 193-195.

277. Equal Access Educ. v. Merten, 305 F. Supp. 2d 585, 591 (E.D. Va. 2004).

278. Undocumented Student Tuition: State Action, NAT'L CONF. ST. LEgISLATURES (May 2011), http://www.ncsl.org/default.aspx?tabid=12846.

279. Id.

280. Merten, 305 F. Supp. 2d at 601-12. There are also a handful of cases post the 1996 laws (IIRIRA and PWROA) involving nonimmigrants who have challenged restrictive policies denying them residency status on similar grounds. See, e.g., Carlson v. Reed, 249 F.3d 876 (9th Cir. 2001); Hein v. Arkansas, 972 F. Supp. 1175 (E.D. Ark. 1997). The cases involving nonimmigrant challenge, however, raise different considerations because federal immigration law does actually prohibit certain nonimmigrants from establishing residency. Thus, decisions on state residency that would contradict this would run into direct conflict with federal immigration policies. 
occupied by Congress in violation of, inter alia, the Supremacy Clause. ${ }^{281}$ The case also raised due process concern in that the law denied undocumented students an ability to apply for post-secondary education. ${ }^{282}$ While the court granted standing in the case, on the merits, it resolved that Virginia's policy was not field preempted by, inter alia, the PRWORA, which addressed only post-secondary monetary assistance, not the admission of such students. ${ }^{283}$ Furthermore, the Virginia court also found that the policy did not conflict with federal immigration laws by finding that Section 505 of the IIRIRA did not in any way imply a mandate for admission by regulating issues of in-state tuition (which presupposes the admission of such students). ${ }^{284}$ On the Due Process Clause, the court, by classifying access to higher education as a benefit, declined to recognize a property interest that could be claimed by the plaintiffs. ${ }^{285}$

Pragmatically, of course, certainly law schools in Virginia and those in states with similar restrictive laws must contend with the Merten precedent and be certain that they would be sued were they to go against the stated state policy. Merten, however, does not definitively settle the constitutionality of restrictive laws and policies that deny access to higher education to undocumented students. It is worth noting, however, that seeking to overturn Merten, at least on preemption ground, represents a double-edged sword for undocumented students. On the outcome, Merten was a defeat for undocumented students in Virginia; however, outside of Virginia, states have adopted friendly policies toward undocumented students. Merten, in fact, lends support to the argument that states are not proscribed by federal law from making their own determinations regarding the admission and treatment of undocumented students into institutions of higher learning. Indeed, experts in this area and proponents for undocumented students, like Michael Olivas, have cited Merten as part of the line of cases upholding the permissiveness of in-statute tuition grants to undocumented students under current federal law. ${ }^{286}$ This is not so, however, with regard to a challenge based on the Due Process Clause. Virginia's treatment of higher education as a mere benefit for purposes of

281. 305 F. Supp. $2 d$ at 601.

282. Id.

283. Id. at 603.

284. Id. at 606.

285. Id.

286. Olivas, supra note 255, at 409 ("In other words, if Merten is upheld in Virginia, then Day must prevail in Kansas. If states such as Virginia are allowed to deny in-state status to undocumented students, then symmetrically, states such as Kansas and Texas should also be able to accord them that status and the lower tuition that comes with it, in accordance with the 1996 federal law."). 
defining the level of protection that undocumented students should receive for being excluded from institutions of higher learning is one that at least deserves greater scrutiny by the courts, including through an examination of the issue as a matter of state constitutional law. ${ }^{287}$ As well, the Plylertreatment of undocumented children as a quasi-suspect class, which was not raised in this litigation with regard to the undocumented plaintiffs, might also be a challenge worth raising in future litigation if Congress fails to resolve the plight of undocumented students.

IV.

\section{TOWARD BEST PRACTICES IN THE EDUCATION OF UNDOCUMENTED LAW STUDENTS}

\section{A. The Admissions and Financial Aid Process}

Very few law schools, if any, have official and open policies specifically addressing the admission of and provision of financial aid for undocumented law students. We urge that all law schools become aware of their own state rules and educate themselves in best practices for handling this uniquely vulnerable group of law school applicants. The following section seeks to contribute to the nascent discussion about best practices for handling the admission and integrated educational experience of these students. It covers the admissions process, including the creation of effective Law School Admissions Council (LSAC) and law school electronic application procedures, the meaningful distinctions between international and undocumented applicants, and the use of ITIN numbers, as well as access to financial aid. The current entwinement of law school admissions practices with LSAC products, practices, and procedures necessitates the inclusion of some suggested practices that relate to the latter service.

\section{Admissions}

As a first principle, throughout the admission process, immigration status ought not be relevant, as no federal law prohibits the admission of undocumented individuals to private or public colleges and universities, nor does any federal law require students to prove citizenship in order to enter institutions of higher education. ${ }^{288}$ Further, law schools are not required

287. See Alan E. Schoenfeld, Challenging the bounds of Education Litigation: Castaneda v. Regents and Daniel v. California, 10 MiCH. J. RACE \& L. 195, 207-210 (2004).

288. See supra notes 200-05 and accompanying text. 
under federal law to inquire into the immigration status of students, nor are they required to report the status of undocumented students. ${ }^{289}$ Schools should be aware, however, that the admission of undocumented students can be regulated by state law or policy, and that developments in some states reflect potential and actual challenges to undocumented individuals' access to higher education. For example, in 2009, the Alabama State Board of Education implemented a policy requiring admissions officials at twoyear community colleges to verify applicant citizenship prior to enrollment. ${ }^{290}$ Thus, to the extent possible, an undocumented immigrant applying to law school should not be subjected to immigration status inquisitions, but rather treated as any other applicant without reference to status.

Law schools should not ask for a student's immigration status; rather, a student should feel free to disclose or not disclose as he or she sees fit. Outreach, educational, or other materials should simply be given to all students, regardless of status, in order to avoid singling out undocumented students. Likewise, LSAC, which has already developed outreach materials for racial and ethnic minority applicants ${ }^{291}$ and LGBT applicants, ${ }^{292}$ and has issued a statement on diversity, ${ }^{293}$ should develop similar such materials for law school applicants with irregular immigration status.

\section{a. LSAC and Law School Electronic Applications}

The process of applying and being admitted to law school has become largely computer-based; thus, "electronic" obstacles to undocumented students applying for law school should be removed, particularly those

289. See Letter from Jim Pendergraph, supra note 271.

290. See Kent Faulk, Alabama's Two-Year Colleges Are Asking For Identification To Curb Admission To Undocumented Students, BIRMINGHAM NEws (Jan. 4, 2009), http://www.al.com/ news/birminghamnews/statebriefs.ssf?/base/news/1231060511138980.xml\&coll=2. Other states, such as South Carolina and Georgia, have passed laws restricting or banning undocumented students from attending public institutions of higher education. See Laura Diamond, Regents Bans Illegal Immigrants from Some Ga. Colleges, ATLANTA J.-Cons. (Oct. 13, 2010), http://www.ajc.com/news/regents-ban-illegal-immigrants-680750.html. The state of Virginia is currently contemplating legislation banning undocumented immigrants from its public colleges and universities. See Virginia to Consider Banning Illegal Immigrants from Public Colleges, AssociATED PRESS (January 12, 2011), http://www.edweek.org/ew/ articles/2011/01/12/397445vuniversitiesillegalimmigrants_ap.html.

291. Racial/Ethnic Minority Applicants, LSAC, http://www.lsac.org/jd/diversity/minoritiesin-legal-education.asp (last visited Jan. 28, 2012).

292. LGBT Applicants, LSAC, http://www.lsac.org/JD/diversity/lgbt-overview.asp (last visited Jan. 28, 2012).

293. Diversity Initiatives, LSAC, http://www.lsac.org/AboutLSAC/about-lsac.asp\#diversity (last visited Jan. 28, 2012). 
related to social security numbers. Presently, the gateway -and potential first obstacle - to admission to law school is the Law School Admission Council (LSAC), a non-profit corporation whose services for law school applicants are almost entirely web-based. In addition to prospective students, almost all accredited law schools in the United States use the computerized and web-based products and services provided by LSAC. ${ }^{294}$ Because both schools and students rely so heavily on LSAC to facilitate the admissions process, it is particularly important that LSAC provide a safe method by which undocumented students can apply, and that law schools work with LSAC to continue best practices or create new ones.

These practices should be guided by the twin concerns of equal access to education via the admissions process and preserving the anonymity of the student with regard to immigration status. During the initial stage of LSAC registration, the first (potential) distinguishing characteristic of an undocumented student from one with regularized immigration status is the absence of a social security number. Fortunately, LSAC accommodates those lacking a social security number by allowing registration to proceed without it. When a person registers for an LSAC account, that person may simply leave the field for "Social Security Number" blank. In response to a blank field in this category, LSAC will automatically generate an identification number for the applicant, typically beginning with the digit sequence "999." This assigned number will then be that student's identification number, both for the student and the law school to input and retrieve information regarding an application. ${ }^{295}$

Because LSAC provides a viable option for student applicants to be identified by a number other than a social security number throughout the admissions process, law schools should simply utilize this number for identification purposes and should not require applicants to provide a social security number. Admittedly, it may pose a challenge to admissions directors and staff insofar as the lack of a social security number can make verifying an applicant's identity more difficult. Some have suggested that a lack of a social security number can seriously impede a law school's attempts to retrieve student undergraduate transcripts, particularly in the case of an applicant with a common name or a name that has changed between their undergraduate and graduate education. Nevertheless,

294. According to the LSAC website, "more than 200 law schools in the United States, Canada, and Australia are members of the Council and benefit from LSAC's services." See About LSAC, LSAC, http://www.Isac.org/AboutLSAC/about-lsac.asp (last visited Jan. 28, 2012).

295. Alternately, any aspiring law student may simply e-mail LSAC and request that an identification number be assigned to him or her. 
accommodations for such students are imperative. Given the relative scarcity and vulnerability of such applicants, the penalty imposed on the undocumented applicant by schools refusing to process an application solely because of the added difficulty of identity verification without a social security number is unduly severe. In the short term, schools should take the extra step of cross-referencing information other than a social security number when reconciling an applicant's identity with any claims on an application for law school. A long-term solution to identity verification involves a more collaborative approach between undergraduate and graduate institutions - that is, by creating an application and recordkeeping process at the undergraduate level that does not involve a social security number, law schools will not face any challenges related to locating and evaluating undergraduate transcripts and other student records. Such a process could assign a number or username during the undergraduate admissions process that could follow a student throughout his or her posthigh school academic career.

\section{b. Distinguishing International from Undocumented Students}

A second potential problem may arise for undocumented applicants during the admissions process: An admissions director, upon receipt of an application containing an LSAC-created identification number, all of which beginning with the digits "999," may assume that such a student is an international student. That assumption is sometimes correct, but not always. As a result of such an assumption, however, admissions staff may automatically channel the application through protocols established by law schools and universities for processing international student applications. ${ }^{296}$ These protocols will presumably have been put into place pursuant to those federal laws and regulations requiring law schools to monitor and report on the admission, status, and progress of students with nonimmigrant visas. ${ }^{297}$ Such monitoring and reporting requirements for international students do not, however, apply to undocumented students. To avoid this confusion, international students under student visa should self-disclose during the application process, and only those self-disclosing should be referred to the university registrar or other entity for participation in the federal reporting

296. One law school reported that all applications containing a "999" LSAC number were referred to the University Registrar, which is then responsible for processing federal and inschool paperwork for international students.

297. The Student and Exchange Visitor Program (SEVP) requires Designated School Officials (DSOs) to update the Department of Homeland Security with information on certain types of nonimmigrant students through its Student and Exchange Visitor Information System (SEVIS). 
program. There remains something of an issue with this approach as it implicates a general policy against forcing an undocumented student to disclose his or her status. By process of elimination, if an applicant is neither international nor a USC, he or she is probably undocumented. Unless a uniform I.D. system is created, this problem may persist.

\section{c. ITIN Numbers}

Undocumented law school applicants with Individual Taxpayer Identification Numbers (ITINs) may in some cases wish to use this number in place of a social security number. In fact, applicants using ITINs may find themselves bypassing impediments that may arise during the application process in the absence of such an identification number. Using an ITIN, however, triggers a different set of concerns. If an undocumented applicant uses an ITIN throughout the admissions process and is admitted, some schools will automatically generate a reward letter on the assumption that the student is a United States Citizen, which may lead the student to believe he or she is eligible for types of aid that the school cannot legally provide. Moreover, an ITIN is not legal identification for purposes other than tax purposes. Because of the potential problems that could arise as a result of its use, an ITIN should not be used or required in place of a social security number during the application process. ${ }^{298}$

\section{Financial Aid}

If an undocumented applicant is admitted to a law school and plans to attend, that school should strive to provide alternative resources for the student. Although an undocumented student is ineligible for federal or state aid, work study, or loan programs, schools can and should refer students to private grants and scholarships and private lending institutions. Private scholarships should be limited to those that do not require the provision of services, as such services could be considered unauthorized employment. Certain law schools may have alumni associations whose members have an interest in providing financial support for undocumented students. Law schools should begin to compile a database of sources of alternative funding for students who are ineligible for state or federal aid or scholarships, and should consider collaborating to create a freestanding foundation that will raise funds for these scholarships. Although a law school admissions staff person or financial aid counselor may not always be able to identify such

298. See Individual Taxpayer Identification Number, INTERNAL REVENUE SERVICE, http://www.irs.gov/individuals/article/0, id=96287,00.html (last updated March 8, 2012). 
sources readily, local community colleges, non-profits, student groups or other community organizations can be better equipped to do so. ${ }^{299}$ Schools should liaise with these groups and solicit assistance in this regard.

Providing tailored advice and assistance regarding financial options can be contingent on a student's self-identifying as undocumented. Although information regarding undocumented status should not be solicited, if it is offered, a student should receive as much information regarding sources of financial aid as possible in order to assist the student in making informed decisions. Admissions officials should be frank about the difficulties involved in obtaining financial backing for law school; this realism, however, should be balanced with the encouragement that it is possible, and that others have successfully obtained funding to attend law school. An admissions official should caution an undocumented student not to apply for federal aid by submitting a FAFSA with a false social security number.

\section{B. Inclusion of Undocumented Students in the Law School's Educational Community}

As legal institutions and law schools have slowly learned, admitting diverse candidates is only the first step of a critically important and rewarding process of diversifying an institution. The responsibility to create an inclusive environment in which undocumented and documented students can learn in-community, mandates sensitization and training of all law school constituencies, as well as some special considerations in curricular options and the delivery of career services.

299. Student groups can be particularly helpful, as other undocumented students can network and assist each other in identifying financial aid supporters. Examples include Rising Immigrant Scholars Through Education (RISE) at UC Berkeley, Students Informing Now (SIN) at UC Santa Cruz, Student Advocates for Higher Education (SAHE) at San Jose State University, Improving Dreams, Equality, Access, and Success (IDEAS) at UCLA, AZDREAM at University of Arizona and Pima Community College, and CADENAS at Arizona State University. MALDEF is a prominent scholarship provider for students of all status. See Scholarship Resources, MALDEF: MEXICAN AMERICAN LEGAL DEFENSE AND EDUCATIONAL FunD, http://www.maldef.org/leadership/scholarships/ (last visited Jan. 28, 2012). Additionally, the San Francisco-based Educators for Fair Consideration (E4FC) has compiled a useful list of financial aid resources for students without social security numbers. Scholarship Lists, EDUCATORS FOR FAIR CONSIDERATION (2011), http://www.e4fc.org/studentresources/ scholarshiplists.html. CUNY Gear Up and the New York State Higher Education Services Corporation also have a joint project to guide undocumented students to financial aid. Scholarship Guide for Undocumented Students, N.Y. GEAR UP, http://www.nygearup.org/ collegesense/students/scholar_undoc.htm (last visited Jan. 28, 2012). 


\section{Avoiding Stigmatization}

Navigating the law school experience puts students under great strain in the best of circumstances. Undocumented law students face the same pressures as students with regular immigration status, added to which is the immense stress of a legal and cultural environment in the United States that is largely hostile to their interests. Consequently, many undocumented law students strive to maintain anonymity with regard to their status, and law schools should assist these students by respecting their privacy. If an undocumented student has disclosed his or her status to a school staff person, that person should take care to preserve the anonymity of the student, meeting privately and individually to discuss academic or other concerns.

In addition to avoiding inquiries into immigration status as a general rule, law schools should adhere to the Family Educational Rights and Privacy Act (FERPA). FERPA is a federal law that protects the privacy of student educational records at both private and public schools. ${ }^{300}$ Generally, FERPA provides students the right to inspect and review their education records and request that a school correct records which they believe to be inaccurate or misleading. ${ }^{301}$ In turn, schools must have written permission from a student before releasing records to a third party, with certain exceptions. ${ }^{302}$ Schools are permitted under FERPA to release certain "directory" information, such as a student's "name, address, telephone number, date and place of birth, honors and awards, and dates of attendance." However, given the urgent privacy concerns involved, schools ought not release such information relating to known undocumented students. ${ }^{303}$

\section{Faculty and Staff Training}

Law schools should train faculty and staff on gauging the appropriateness of questions to students regarding immigration status. Educators and staff should understand that immigration status is wholly irrelevant to a student's ability to receive a legal education and thrive in law school, and that inquiries into status can make these students feel

300. 20 U.S.C.A. $\S 1232$ g (West 2010); 34 C.F.R. $\S 99$ (2012).

301. 20 U.S.C.A. $\$ 1232 \mathrm{~g}(\mathrm{a})(1)(\mathrm{A})-(\mathrm{B}),(\mathrm{a})(2)$.

302. These exceptions can be found at 34 C.F.R. $\S 99.31$ (2012).

303. A general overview of FERPA and contact information for individuals with questions regarding this law can be found online. Family Educational Rights and Privacy Act (FERPA), U.S. DEPARTMENT EDUC. (Apr. 8, 2011), http://www2.ed.gov/policy/gen/guid/fpco/ferpa/ index.html. 
uncomfortable, stigmatized, or threatened. If a student self-identifies to a faculty member or staff person as undocumented, that information should be treated as confidential between student and staff. Sharing this information indicates a high degree of trust, and that trust should be carefully maintained. Training law school faculty and staff on this issue is crucial towards integrating these students into the law school environment. ${ }^{304}$ To this end, law school should create policies that delineate appropriate interactions with law students regarding immigration status, which would address privacy, stigmatization, and other such concerns.

\section{Sensitizing Documented Students}

As the growing elementary and secondary school bullying prevention movement demonstrates, the reaction of fellow students can have remarkably positive - or tragic - consequences for students who do not pass under the contemporary radar of "normalcy" and "difference." Using guides such as the ABA recommendations for law schools contained in the Report on Diversity and Inclusion discussed above, law school administrations should be proactive and creative in finding effective ways to sensitize the student body to issues of difference, including immigration status, preferably before the next undocumented student matriculates at the law school. Faculty should be given ongoing training and support for dealing with sensitive questions in the classroom, including the intersection of their teaching areas with immigration status.

\section{Career Services}

Employment prospects for undocumented law students are undeniably limited. Future changes in the law, however, may allow these students to work legally in the United States. If an undocumented student self-discloses and solicits in-school employment advice, law school staff should guide the student to unpaid internships and externships, pro-bono volunteer work, and law school legal clinics where the student can legally gain experience, irrespective of whether current U.S. law permits the student to be gainfully employed. Provided these types of work opportunities are unpaid, a law school runs no risk of contravening federal laws regarding employment of undocumented individuals. For undocumented students not expecting work

304. For useful guides for educators and other university staff regarding undocumented students, see Educator Guides, EDUCATORS FOR FAIR CONSIDERATION, http://www.e4fc.org/ educatorresources/educatorguides.html (last visited Jan. 28, 2012). 
authorization before entering the work force, remunerated employment advice should be limited to placements in countries other than the United States where that student may legally work. Generally, in order to provide options for undocumented students who have not disclosed their status, career staff should provide employment options to students beyond U.S. borders. In the case of a student who will be work authorized before a postgraduate work placement commences, career services staff can counsel the student regarding paid employment options within the United States.

\section{Experiential Education}

A few special issues arise with regard to undocumented student participation in experiential education, such as clinics, externships, and pro bono service. In general, foreign nationals are only permitted to work if they are explicitly authorized under U.S. law to be employed. ${ }^{305}$ Similarly, employers are not permitted to employ a foreign national if the employer knows that the worker is not work-authorized. ${ }^{306}$ However, immigration law makes an exception for unremunerated work. ${ }^{307}$ Given that, at least at the present juncture, law students are permitted to practice law and to receive credit only for unpaid work, ${ }^{308}$ participation in all of these programs is open to undocumented law students. If certification to practice as a student under state licensing laws is a requirement of a particular clinical course, a good moral character showing may become an element in the process. ${ }^{309}$ In student certification processes where law schools attest to the student's good moral character, it is appropriate for the school to handle the character inquiry as it would with any other student, relying on school records and recalling that undocumented status is a civil violation. As discussed in the analysis on character and fitness determinations above, each law school must develop their own policy as appropriate for their relevant state bar jurisprudence. ${ }^{310}$

305. See 8 U.S.C.A. $\S 1324 a(a)(1)(A)$ (West 2011) ("It is unlawful for a person or other entity - to hire, or to recruit or refer for a fee, for employment in the United States an alien knowing the alien is an unauthorized alien ... with respect to such employment.").

306. See id.

307. See Matter of Hall, 18 I. \& N. Dec. 203, 205-06 (BIA 1982) (implying that if respondent had not received compensation then he would be an unpaid volunteer and not in violation of immigration law).

308. ABA STANDARDS, supra note 39, at 27 (Standard 305: Interpretation 305-3).

309. See generally Sara B. Lewis, Rite of Professional Passage: A Case for the Liberalization of Student Practice Rules, 82 MARQ. L. REV. 205, 220-25 (1998); see also Joan Wallman Kuruc \& Rachel A. Brown, Student Practice Rules in the United States, 63 B. EXAMINER 40, 42 (1994).

310. See supra Part I.B. 
Another consideration with regard to experiential learning involves reimbursements. Clinical students, legal services externs, and pro bono volunteers typically receive reimbursement for incidental expenses such as transportation, food costs, out of pocket case-related expenses, and even temporary room and board when the program requires travel and overnight stays. These reimbursements should not be regarded as remuneration, because the underlying work of the clinical students, externs and pro bono volunteers inures primarily to their benefit rather than to the benefit of the law school or placement site. Immigration jurisprudence is strict with regard to remuneration: in its 1982 ruling in Matter of Hall, the Board of Immigration Appeals held that a foreign national who had volunteered with a church, but had received room, board and pocket change, had engaged in employment for the purposes of the Immigration and Nationality Act. ${ }^{311}$ The volunteer work in Matter of Hall did not, however, take place in an educational context. There appears to be no published decision applying Matter of Hall to the service-learning context. There is, however, jurisprudence under the Fair Labor Standards Act finding that unpaid experiential programs do not run afoul of child labor and wage and hour laws. The Sixth Circuit Court of Appeals recently held that the "primary benefit" of practical training courses at a Seventh Day Adventist school runs to the students rather than to the school, such that the child labor laws were not violated by the work requirement of that program. ${ }^{312}$ Using this jurisprudence as an analogy, it is clear that the primary benefit of clinical, externship and pro bono work runs to the law student, in the form of credit, discharge of a law school pro bono requirement, or developing legal skills. Reimbursing a law school student for expenses incident to these activities is simply a part of the educational process and does not constitute remuneration for the purposes of the Immigration and Nationality Act.

\section{Work Study}

The considerable expense of law school has a disproportionately sizeable impact on undocumented students. Unfortunately, however, just as IIRIRA makes an undocumented student ineligible for federal or most state

311. See Matter of Hall, 18 I. \& N. Dec. at 206.

312. See Solis v. Laurelbrook Sanitarium and Sch., Inc., 642 F.3d 518, 519 (6th Cir. 2011); see also WAGE AND HOUR DIVISION, U.S. Department OF LABOR, FACT SHEET \#71: INTERNSHIP PROGRAMS UNDER THE FAIR LABOR STANDARDS ACT (2010), available at http://www.dol.gov/whd/regs/compliance/whdfs71.pdf (listing factors by which a worker in the for-profit sector can be considered an intern and thus excluded from wage and hour protections). 
financial loans and scholarships, so too does the Immigration Reform and Control Act ("IRCA") of 1986 bar employers from hiring undocumented immigrants. ${ }^{313}$ Any work study or for-pay hiring arrangements with a known undocumented student would cause the university to violate IRCA. Thus, law schools should advise against work-study as an option for undocumented students. In addition, to protect an undocumented student from incurring liability under IRCA, other immigration statutes, and fraud statutes, the institution should be careful to advise all students about the dangers of presenting false documentation to obtain university-paid or any other type of paid employment, while reassuring work-authorized students of their eligibility to work.

\section{Graduation and Bar Admission}

Law school counselors should inform interested students regarding potential impediments to admission to the bar, including which state bars request social security numbers or immigration status; which state bars conduct background checks on applicants to the bar; and/or which state bars require relevant disclosures of applicants in order to pass character and fitness tests, highlighting how irregular immigration status could figure into these tests.

\section{CONCLUSION}

In preparation for this paper, Tom Herman, one of our exceptional law student research assistants, was able to interview a few aspiring undocumented law students. One such student was Frank, ${ }^{314}$ a recent graduate of a nationally ranked university in the southern United States. Frank double majored in Philosophy and Political Science, and wrote an Honors thesis that received the highest distinction from his defense panel. As a high school student, Frank excelled both academically and in extracurricular activities, and, on the strength of his achievements, was admitted to the university on a full-tuition scholarship for debate. Higher education has nurtured Frank's natural curiosity and fierce intelligence, and he went on to achieve a 3.94 grade point average overall. He also participated in debate tournaments, excelling in this arena as well. Now, having recently graduated, two interests have directed Frank towards the

313. The Immigration Reform and Control Act, 8 U.S.C. $§ 1324$ (a) (2006).

314. Name changed to protect interviewee. Interview notes and permission on file with authors. 
next step in his life: using his undergraduate education in the most fruitful way possible, and living a life of service to the underserved and disenfranchised. Between these noble intentions and his high-achieving background in debate, and after considering a number of different graduate programs, Frank has decided that law school is the best fit for his personal and professional aspirations. There is, however, one catch: Despite having lived in the United States since the age of five months, Frank is not authorized to live or work here.

For aspiring law students like Frank, applying to law school raises a host of issues, many of which are the province of any prospective graduate student-basic but substantial concerns such as admissions standards, tuition financing, coursework, internships, and, perhaps most importantly, employment possibilities. With Frank, however, and for students like him, being undocumented adds a layer of issues-obstacles, in truth-to becoming a practicing attorney in the United States. In other words, undocumented applicants must engage with the challenges of applying to law school on more consequential terms, navigating the intricacies of federal and state laws on financial assistance, employment, and educational privacy as they relate to immigration status, as well as state bar admissions rules and standards to which applicants and law schools adhere. Failing to properly appreciate or fully comprehend any of these obstacles can, at best, put an undocumented law student at risk of squandering valuable time and resources and, at worst, put them in danger of being deported from the United States.

Unfortunately, given the recent emergence of the issue, the sensitivity of the privacy concerns, and the complexity and variety of legal matters involved, few resources have yet been comprehensively compiled and made available to undocumented college graduates who wish to attend law school, either from academic or institutional sources. In fact, as of this writing, very few institutions of higher learning in the United States have publicly made available (i.e. web-accessible) school policies specifically addressing the admission and matriculation of undocumented students. ${ }^{315}$

315. See, e.g., Admission of Undocumented Students to Academic Study, supra note 9; International Applicants, U. CHI., https://collegeadmissions.uchicago.edu/apply/applicants/ international/ (last visited Jan. 28, 2012) (describing university's policy towards admission of international students). The University of Chicago is an example of a more oblique approach to a school policy regarding undocumented students. Here, the University of Chicago, without singling out undocumented applicants, has published a policy under the "International Student" section of their website, stating, "UChicago considers you an international applicant to the College if you are neither a U.S. citizen nor a U.S. permanent resident, regardless of where in the world you live." Id. Such a policy signals an open admissions approach without explicitly 
This lack of clarity can be dissuasive to such students pursuing legal studies, or result in their approaching the process under misconceptions or without sufficient information. And while some community organizations and policy programs have published guides for students wishing to understand the legal and financial ramifications of applying to and attending undergraduate programs as an undocumented student, ${ }^{316}$ nothing similar exists for those wishing to understand the nuances of the law school admission, study, and post-graduate experience.

With these challenges in mind, this paper is written in the spirit of inclusiveness, fair treatment, and equal opportunity aptly encapsulated by Justice Brennan in the landmark Plyler v. Doe decision:

[E]ducation has a pivotal role in maintaining the fabric of our society and in sustaining our political and cultural heritage: the deprivation of education takes an inestimable toll on the social, economic, intellectual, and psychological well-being of the individual, and poses an obstacle to individual achievement. ${ }^{317}$

It is also written against the backdrop of Congress's recent failure to expand upon the promise of Plyler by passing the DREAM Act ${ }^{318}$ and the years of stillborn Congressional attempts at more comprehensive immigration reform. ${ }^{319}$ This legislative inaction, however, while impeding some of the forward momentum of undocumented students, has not undermined their promise, potential, or inherent worth as members of this society - nor has it deprived Justice Brennan's words of their urgency.

As Professor Park observes, throughout the unique U.S. history of regimes like the fugitive slave act and Chinese exclusion:

Many Americans have not, in fact, treated undocumented aliens as wrongdoers deserving of removal-even though they are aware

referring to undocumented applicants. See infra Appendix B for the handful of other available policies.

316. See Securing Equal Opportunity for Academic Achievement, MALDEF, http://www.maldef.org/education/public policy/index.html (last visited Jan. 28, 2012); Student Resources, EDUCATORS FOR FAIR CONSIDERATION, http://www.e4fc.org/studentresources.html (last visited Jan. 28, 2012); H. Pierce McNair Jr., et al., Undocumented College Student Enrollment: A Policy Discussion, EJOURNAL OF EDUC. POL'Y, 2010, https://www4.nau.edu/cee/jep/journals.aspx?id=343; SCHOLARSHIPS A-Z, EDUCATIONAL RESOURCE GUIDE FOR STUDENTS REGARDLESS OF IMMIGRATION STATUS (2009), available at http://www.scholarshipsaz.org/collatera1/resourceguide.pdf.

317. 457 U.S. 202, 203 (1982).

318. S. 3827, 111th Cong. (2010), available at http://frwebgate.access.gpo.gov/cgibin/getdoc.cgi?dbname=111_cong_bills\&docid=f:s3827pcs.txt.pdf.

319. Senate Vote $278-$ Fails to Advance Dream Act, N.Y. TIMEs, http://politics.nytimes.com/congress/votes/111/senate/2/278 (last visited Mar. 25, 2012). 
that federal law prohibits these aliens from being in the United States at all, citizens and public institutions here have helped these persons across a wide range of circumstances, either by ignoring or by disobeying settled public law. ${ }^{320}$

Today's educational institutions have the luxury of reaching out to assist these promising students without having to "ignore or disobey settled law." Simply by developing careful policies, they may assist deserving aspiring student and lawyers who come from one of America's most vulnerable communities. It is incumbent upon those institutions and individuals with the power to act, inform, and work with undocumented students-law schools, law graduates, academic counselors, community and student groups - and upon undocumented students themselves, to address this issue.

\section{Appendix A: Table Bar Admission Rules and Applications that May Affect Undocumented Applicants ${ }^{321}$}

\begin{tabular}{|c|c|c|}
\hline State & Requests Immigration Status & $\begin{array}{l}\text { Requests Social Security } \\
\text { Number }\end{array}$ \\
\hline \multirow[t]{2}{*}{ Alabama } & \multicolumn{2}{|c|}{$\begin{array}{l}\text { Full Disclosure: "Applications for admission to the Alabama } \\
\text { State Bar, whether filed as a registrant under Rule I or as } \\
\text { applicant under this Rule, are continuing in nature and must give } \\
\text { correctly and fully the information therein sought as of the date } \\
\text { that the applicant is sworn in as a member of the Alabama State } \\
\text { Bar. To that end, every applicant or registrant shall immediately } \\
\text { inform the Secretary of the Alabama State Bar of any change or } \\
\text { discovered error in the requested information that may occur } \\
\text { between the time that information is furnished to the Alabama } \\
\text { State Bar and the date of admission. The Board may require that } \\
\text { all the information furnished, be given under oath. As a condition } \\
\text { for admission into the bar examination, every applicant shall state } \\
\text { under oath when filing an Application for Admission in the } \\
\text { Alabama State Bar that all information in every application and } \\
\text { amendments thereto previously submitted is true and complete." } \\
\text { R. GOVERNING ADMISSION TO THE ALA. STATE BAR II(A). }\end{array}$} \\
\hline & State Bar Rule: N/A & \\
\hline
\end{tabular}

320. John S.W. Park (unpublished manuscript) (on file with authors).

321. Most Bar admission rules do not address what information is to be contained within the application. Instead, the rules generally focus on the composition of the Board of Bar Examiners, the subjects to be tested on the exam, the educational requirements to sit for the exam, and the process of appeals for a denied application. 


\begin{tabular}{|c|c|c|}
\hline $\begin{array}{l}\text { Alabama } \\
\text { (continued) }\end{array}$ & $\begin{array}{l}\text { Application: Asks whether the } \\
\text { applicant is a U.S. citizen and, if } \\
\text { not, asks if the applicant has } \\
\text { filed a Declaration of Intent to } \\
\text { become a citizen. If yes to the } \\
\text { latter, asks where and when the } \\
\text { Declaration was filed. Also asks } \\
\text { for the Declaration number and } \\
\text { a copy of the Declaration itself. }\end{array}$ & $\begin{array}{l}\text { Application: For Registration as } \\
\text { a Law Student, asks for the } \\
\text { applicant's social security } \\
\text { number. }\end{array}$ \\
\hline \multirow[t]{3}{*}{ Alaska } & \multicolumn{2}{|l|}{ Full Disclosure: N/A } \\
\hline & $\begin{array}{l}\text { State Bar Rule: "Any person } \\
\text { seeking admission to the } \\
\text { practice of law shall file with } \\
\text { the Executive Director at the } \\
\text { office of the Alaska Bar } \\
\text { Association an application in the } \\
\text { form provided by the board. The } \\
\text { application shall be made under } \\
\text { oath and contain such } \\
\text { information relating to the } \\
\text { applicant's age, residence, } \\
\text { addresses, citizenship, } \\
\text { occupations, general education, } \\
\text { legal education, moral character } \\
\text { and other matters as may be } \\
\text { required by the Board." } \\
\text { ALASKA BAR R. } 3 \S 2 \text {. }\end{array}$ & $\begin{array}{l}\text { State Bar Rule: "[T] } \\
\text { application must contain the } \\
\text { applicant's social security } \\
\text { number." } \\
\text { ALASKA BAR R. } 3 \S 2 . \\
\end{array}$ \\
\hline & $\begin{array}{l}\text { Application: Asks whether the } \\
\text { applicant is a U.S. citizen, a } \\
\text { resident alien, or other (please } \\
\text { explain). }\end{array}$ & $\begin{array}{l}\text { Application: Asks for the } \\
\text { applicant's social security } \\
\text { number. }\end{array}$ \\
\hline \multirow{2}{*}{$\begin{array}{l}\text { American } \\
\text { Samoa }\end{array}$} & \multicolumn{2}{|l|}{ Full Disclosure: N/A } \\
\hline & $\begin{array}{l}\text { State Bar Rule: "Any person } \\
\text { seeking admission to the } \\
\text { practice of law in American } \\
\text { Samoa must file with the Clerk } \\
\text { of Courts a formal application in } \\
\text { a form furnished by the Clerk, } \\
\text { which must be made under oath } \\
\text { and must contain such } \\
\text { information relating to the } \\
\text { applicant's age, social security } \\
\text { number, residences, addresses, } \\
\text { citizenship, occupations, general }\end{array}$ & $\begin{array}{l}\text { State Bar Rule: "Any person } \\
\text { seeking admission to the } \\
\text { practice of law in American } \\
\text { Samoa must file with the Clerk } \\
\text { of Courts a formal application in } \\
\text { a form furnished by the Clerk, } \\
\text { which must be made under oath } \\
\text { and must contain such } \\
\text { information relating to the } \\
\text { applicant's age, social security } \\
\text { number, residences, addresses, } \\
\text { citizenship, occupations, general }\end{array}$ \\
\hline
\end{tabular}




\begin{tabular}{|c|c|c|}
\hline \multirow[t]{2}{*}{$\begin{array}{l}\text { American } \\
\text { Samoa } \\
\text { (continued) }\end{array}$} & $\begin{array}{l}\text { education, Legal education, and } \\
\text { moral character." } \\
\text { AM. SAM. HCR } 134 .\end{array}$ & $\begin{array}{l}\text { education, Legal education, and } \\
\text { moral character." } \\
\text { AM. SAM. HCR } 134 .\end{array}$ \\
\hline & Application: N/A & Application: N/A \\
\hline \multirow[t]{3}{*}{ Arizona } & \multicolumn{2}{|l|}{ Full Disclosure: N/A } \\
\hline & State Bar Rule: N/A & State Bar Rule: N/A \\
\hline & $\begin{array}{l}\text { Application: Asks whether the } \\
\text { applicant is a U.S. citizen and, if } \\
\text { not, asks what the applicant's } \\
\text { immigration status is. If not a } \\
\text { citizen, the applicant is required } \\
\text { to mail copies of official } \\
\text { documentation of his or her } \\
\text { immigration status. }\end{array}$ & $\begin{array}{l}\text { Application: Asks for the } \\
\text { applicant's social security } \\
\text { number. }\end{array}$ \\
\hline \multirow[t]{3}{*}{ Arkansas } & \multicolumn{2}{|l|}{ Full Disclosure: N/A } \\
\hline & $\begin{array}{l}\text { State Bar Rule: "Candidates } \\
\text { may be a United States citizen, } \\
\text { an alien lawfully admitted for } \\
\text { permanent residence, or an alien } \\
\text { otherwise authorized to work or } \\
\text { study lawfully in the United } \\
\text { States." } \\
\text { ARK. R. GOVERNING BAR } \\
\text { ADMISSION XII(2). } \\
\end{array}$ & State Bar Rule: N/A \\
\hline & $\begin{array}{l}\text { Application: Asks whether the } \\
\text { applicant is a U.S. citizen and, if } \\
\text { not, requires the applicant to } \\
\text { provide evidence of residency } \\
\text { status. }\end{array}$ & $\begin{array}{l}\text { Application: Asks for the } \\
\text { applicant's social security } \\
\text { number but states that "the } \\
\text { provision of your social security } \\
\text { number is voluntary, pursuant to } \\
\text { the Federal Privacy Act of } 1974 . \\
\text { Your social security number } \\
\text { will be used for purposes of } \\
\text { investigation and verification, in } \\
\text { order to avoid errors of identity. } \\
\text { The request for your social } \\
\text { security number is made by the } \\
\text { Arkansas State Board of Law } \\
\text { Examiners pursuant to authority } \\
\text { given it under the } \\
\text { Rules Governing Admission to } \\
\text { the Bar of Arkansas." }\end{array}$ \\
\hline
\end{tabular}




\begin{tabular}{|c|c|c|}
\hline \multirow[t]{3}{*}{ California } & \multicolumn{2}{|c|}{$\begin{array}{l}\text { Full Disclosure: "A document, which must be complete as } \\
\text { defined by the instructions for filing, is deemed filed upon } \\
\text { receipt." } \\
\text { R. STATE BAR CAL. } 4.5 \text {. }\end{array}$} \\
\hline & State Bar Rule: N/A & $\begin{array}{l}\text { State Bar Rule: "The applicant } \\
\text { is required by law either to } \\
\text { provide the Committee with a } \\
\text { Social Security Number or to } \\
\text { request an exemption because of } \\
\text { ineligibility for a Social Security } \\
\text { Number." } \\
\text { R. STATE BAR CAL. 4.16(B). }\end{array}$ \\
\hline & Application: N/A & Application: N/A \\
\hline \multirow[t]{3}{*}{ Colorado } & \multicolumn{2}{|l|}{ Full Disclosure: N/A } \\
\hline & State Bar Rule: N/A & State Bar Rule: N/A \\
\hline & $\begin{array}{l}\text { Application: Asks whether the } \\
\text { applicant is a U.S. citizen and, if } \\
\text { not, under what type of visa the } \\
\text { applicant is living in the U.S. } \\
\text { The applicant is required to } \\
\text { attach a copy, front and back, of } \\
\text { the visa or Alien Registration } \\
\text { Receipt. The applicant is also } \\
\text { required to provide the date of } \\
\text { issue, expiration date, origin of } \\
\text { issue, and alien registration } \\
\text { number for the visa or Alien } \\
\text { Registration Receipt. }\end{array}$ & $\begin{array}{l}\text { Application: Asks for the } \\
\text { applicant's social security } \\
\text { number. }\end{array}$ \\
\hline \multirow[t]{2}{*}{ Connecticut } & \multicolumn{2}{|l|}{ Full Disclosure: N/A } \\
\hline & $\begin{array}{l}\text { State Bar Rule: "To entitle an } \\
\text { applicant to admission to the } \\
\text { bar, except under Sections } 2-13 \\
\text { through } 2-15 \text { of these rules, the } \\
\text { applicant must satisfy the } \\
\text { committee that } \\
\text { (1) The applicant is a citizen of } \\
\text { the United States or an alien } \\
\text { lawfully residing in the United } \\
\text { States." } \\
\text { CONN. R. SUPER, CT. } § 2-8 \text {. }\end{array}$ & State Bar Rule: N/A \\
\hline
\end{tabular}




\begin{tabular}{|c|c|c|}
\hline $\begin{array}{l}\text { Connecticut } \\
\text { (continued) }\end{array}$ & $\begin{array}{l}\text { Application: Asks the applicant } \\
\text { to check one of the following } \\
\text { boxes: } \\
\text { - "I am a natural born citizen of } \\
\text { the United States" } \\
\text { "II am a naturalized citizen of } \\
\text { the United States" (requires the } \\
\text { applicant to attach a copy of his } \\
\text { or her naturalization certificate } \\
\text { and date of naturalization) } \\
\text { - "I am an alien lawfully } \\
\text { residing in the United States" } \\
\text { (requires the applicant to } \\
\text { describe his or her immigration } \\
\text { status and provide his or her } \\
\text { alien registration number and a } \\
\text { copy of his or her resident alien } \\
\text { card; if the applicant does not } \\
\text { have an alien registration } \\
\text { number or resident alien card, } \\
\text { he or she is required to explain } \\
\text { and attach a copy of his or her } \\
\text { UsCIS-issued documents) }\end{array}$ & $\begin{array}{l}\text { Application: Asks for the } \\
\text { applicant's social security } \\
\text { number but states that "pursuant } \\
\text { to } 42 \text { U.S.C. } \S 666(\mathrm{a})(13)(\mathrm{A}), \\
\text { applicants are advised that } \\
\text { providing their Social Security } \\
\text { Number is required. The } \\
\text { information is requested } \\
\text { pursuant to Practice book } \S 2-4 \\
\text { and Article III of the } \\
\text { Regulations of the Bar } \\
\text { Examining Committee. The } \\
\text { information will be used to } \\
\text { match various records with your } \\
\text { file." }\end{array}$ \\
\hline \multirow[t]{3}{*}{ Delaware } & \multicolumn{2}{|l|}{ Full Disclosure: N/A } \\
\hline & State Bar Rule: N/A & State Bar Rule: N/A \\
\hline & $\begin{array}{l}\text { Application: Asks whether the } \\
\text { applicant is a U.S. citizen and, if } \\
\text { not, what the applicant's } \\
\text { immigration status is. }\end{array}$ & $\begin{array}{l}\text { Application: Asks for the } \\
\text { applicant's social security } \\
\text { number. }\end{array}$ \\
\hline \multirow[t]{3}{*}{$\begin{array}{l}\text { District of } \\
\text { Columbia }\end{array}$} & \multicolumn{2}{|c|}{$\begin{array}{l}\text { Full Disclosure: "The Director shall examine each application to } \\
\text { determine the applicant's eligibility and to verify the } \\
\text { completeness of the application. If eligibility is not demonstrated, } \\
\text { the applicant shall be permitted to furnish additional information. } \\
\text { If the application is not complete, either it shall be returned to the } \\
\text { applicant for completion or the needed information shall be } \\
\text { requested by letter." } \\
\text { D.C. CT. APP. R. 46(B)(6). }\end{array}$} \\
\hline & State Bar Rule: N/A & State Bar Rule: N/A \\
\hline & Application: N/A & $\begin{array}{l}\text { Application: Asks for the } \\
\text { applicant's social security } \\
\text { number. }\end{array}$ \\
\hline Florida & \multicolumn{2}{|c|}{$\begin{array}{l}\text { Full Disclosure: "Applicants are required to file complete and } \\
\text { sworn Bar Applications." } \\
\text { R. FLA. SUP. CT. RELATING TO ADMISSIONS TO THE BAR 1-14.1. }\end{array}$} \\
\hline
\end{tabular}


[Ariz. St. L.J.

\begin{tabular}{|c|c|c|}
\hline \multirow[t]{2}{*}{$\begin{array}{l}\text { Florida } \\
\text { (continued) }\end{array}$} & State Bar Rule: N/A & $\begin{array}{l}\text { State Bar Rule: "The name, date } \\
\text { of birth, Social Security number, } \\
\text { and date of application will be } \\
\text { provided for placement in a } \\
\text { national data bank operated by, } \\
\text { or on behalf of, the National } \\
\text { Conference of Bar Examiners." } \\
\text { R. FLA. SUP. CT. RELATING TO } \\
\text { ADMISSIONS TO THE BAR 1- } \\
\text { 63.2. }\end{array}$ \\
\hline & $\begin{array}{l}\text { Application: Asks for the } \\
\text { applicant's immigration status } \\
\text { and proof of immigration status. }\end{array}$ & $\begin{array}{l}\text { Application: Asks for the } \\
\text { applicant's social security } \\
\text { number. }\end{array}$ \\
\hline \multirow[t]{2}{*}{ Georgia } & \multicolumn{2}{|c|}{$\begin{array}{l}\text { Full Disclosure: "It is the obligation of the applicant to submit a } \\
\text { complete, accurate and timely application in conformity with } \\
\text { these Rules." } \\
\text { SUP. CT. GA. R. GOVERNING ADMISSION TO THE PRACTICE OF } \\
\text { LAW } \S 3 \text {. }\end{array}$} \\
\hline & State Bar Rule: N/A & $\begin{array}{l}\text { State Bar Rule: "All } \\
\text { amendments must be submitted } \\
\text { in writing and must include your } \\
\text { Social Security number." } \\
\text { SUP. CT. GA. R. GOVERNING } \\
\text { ADMISSION TO THE PRACTICE } \\
\text { OF LAW N. 9. } \\
\\
\text { "The name, address, date of } \\
\text { birth and social security number } \\
\text { of each applicant for } \\
\text { certification of fitness to } \\
\text { practice law may be furnished to } \\
\text { the National Conference of Bar } \\
\text { Examiners for dissemination to } \\
\text { the bar admissions authority of } \\
\text { any United States jurisdiction } \\
\text { upon request." } \\
\text { SUP. CT. GA. R. GOVERNING } \\
\text { ADMISSION TO THE PRACTICE } \\
\text { OF LAW 4(b). }\end{array}$ \\
\hline
\end{tabular}




\begin{tabular}{|c|c|c|}
\hline $\begin{array}{l}\text { Georgia } \\
\text { continued) }\end{array}$ & $\begin{array}{l}\text { Application: The Moral Fitness } \\
\text { Application states that } \\
\text { "[a]pplicants who are not U.S. } \\
\text { citizens or do not have } \\
\text { Permanent Resident status in the } \\
\text { U.S. must print, complete, and } \\
\text { submit the Non-Immigrant } \\
\text { Affidavit and required } \\
\text { documentation along with the } \\
\text { Fitness Application." The Non- } \\
\text { Immigrant Affidavit requires the } \\
\text { applicant to have a visa and } \\
\text { intend to maintain his or her } \\
\text { present status in accordance } \\
\text { with US immigration law. }\end{array}$ & $\begin{array}{l}\text { Application: Asks for the } \\
\text { applicant's social security } \\
\text { number. }\end{array}$ \\
\hline \multirow[t]{3}{*}{ Hawaii } & \multicolumn{2}{|c|}{$\begin{array}{l}\text { Full Disclosure: "The application is of a continuing nature and } \\
\text { must be correct as of the date of admission to the bar." } \\
\text { SuP. CT. HAW. R. 1.5(a)(3). }\end{array}$} \\
\hline & State Bar Rule: N/A & State Bar Rule: N/A \\
\hline & Application: N/A & $\begin{array}{l}\text { Application: Asks for the } \\
\text { applicant's social security } \\
\text { number. }\end{array}$ \\
\hline \multirow[t]{3}{*}{ Illinois } & \multicolumn{2}{|c|}{$\begin{array}{l}\text { Full Disclosure: "At all times prior to his or her admission to the } \\
\text { bar of this state, each law student registrant and applicant is under } \\
\text { a continuing duty to supplement and continue to report fully and } \\
\text { completely to the Board of Admissions to the Bar and to the } \\
\text { Committee on Character and Fitness all information required to } \\
\text { be disclosed pursuant to any and all application documents and } \\
\text { such further inquiries prescribed by the Board and the } \\
\text { Committee." } \\
\text { ILL. SUP. CT. R. 708(e). }\end{array}$} \\
\hline & State Bar Rule: N/A & State Bar Rule: N/A \\
\hline & Application: N/A & $\begin{array}{l}\text { Application: Asks for the } \\
\text { applicant's social security } \\
\text { number. }\end{array}$ \\
\hline Indiana & \multicolumn{2}{|c|}{$\begin{array}{l}\text { Full Disclosure: "The applicant has the absolute duty to inform } \\
\text { the Board with full candor of any facts which bear, even } \\
\text { remotely, upon the question of the applicant's character and } \\
\text { fitness and general qualifications to practice law, which } \\
\text { obligation continues from the date of application to the time of } \\
\text { admission, and includes the obligation to promptly and to fully } \\
\text { inform the Board of any such facts occurring or discovered prior } \\
\text { to admission." } \\
\text { IND. CT. R. } 12 \S 2 \text {. }\end{array}$} \\
\hline
\end{tabular}




\begin{tabular}{|c|c|c|}
\hline \multirow[t]{2}{*}{$\mid \begin{array}{l}\text { Indiana } \\
\text { (continued) }\end{array}$} & State Bar Rule: N/A & $\begin{array}{l}\text { State Bar Rule: "The Board is } \\
\text { authorized to disclose } \\
\text { information relating to } \\
\text { applicants or members of the bar } \\
\text { only as follows: } \\
\text { (C) The name, date of birth, } \\
\text { Social Security number, and } \\
\text { other information relating to a } \\
\text { bar application, an applicant, } \\
\text { and the result of the bar } \\
\text { application for placement in a } \\
\text { national data bank operated by } \\
\text { or on behalf of the National } \\
\text { Conference of Bar Examiners." } \\
\text { IND. CT. R. } 19 \S 3 \text {. }\end{array}$ \\
\hline & Application: N/A & $\begin{array}{l}\text { Application: Asks for the } \\
\text { applicant's social security } \\
\text { number. }\end{array}$ \\
\hline \multirow[t]{3}{*}{ Iowa } & \multicolumn{2}{|c|}{$\begin{array}{l}\text { Full Disclosure: "Every applicant for admission to the bar shall } \\
\text { make application, under oath, and upon a form furnished by the } \\
\text { assistant director... If any changes occur after the application is } \\
\text { filed which affect the applicant's answers, the applicant must } \\
\text { amend the application. A new and complete application shall be } \\
\text { filed for each examination for admission." } \\
\text { IOWA CT. R. 31.5(2). }\end{array}$} \\
\hline & State Bar Rule: N/A & State Bar Rule: N/A \\
\hline & $\begin{array}{l}\text { Application: Asks of what } \\
\text { country the applicant is a } \\
\text { citizen. }\end{array}$ & $\begin{array}{l}\text { Application: Asks for the } \\
\text { applicant's social security } \\
\text { number but states that the } \\
\text { provision of the number is } \\
\text { voluntary. }\end{array}$ \\
\hline \multirow[t]{2}{*}{ Kansas } & \multicolumn{2}{|c|}{$\begin{array}{l}\text { Full Disclosure: "Each applicant for admission to the bar has a } \\
\text { duty to be candid and to respond carefully and accurately to } \\
\text { questions in all phases of the application and admission process. } \\
\text { Each applicant must respond fully to all inquiries." } \\
\text { KAN. SuP. CT. R. 714(a). } \\
\text { "Failure to accurately and completely answer all questions on the } \\
\text { application, failure to disclose requested information, lack of } \\
\text { candor in any answer or falsification of any answer may result in } \\
\text { denial of an application for admission to practice law in Kansas } \\
\text { and may constitute grounds for revocation of the license to } \\
\text { practice law granted to any person based thereon." } \\
\text { KAN. SuP. CT. R. 714(b). }\end{array}$} \\
\hline & State Bar Rule: N/A & State Bar Rule: N/A \\
\hline
\end{tabular}




\begin{tabular}{|c|c|c|}
\hline $\begin{array}{l}\text { Kansas } \\
\text { (continued) }\end{array}$ & $\begin{array}{l}\text { Application: Asks whether the } \\
\text { applicant is a U.S. citizen and, if } \\
\text { not, asks of what country the } \\
\text { applicant is a citizen. States that } \\
\text { "if not a United States citizen, } \\
\text { describe your immigration status } \\
\text { and provide your alien } \\
\text { registration number and a copy } \\
\text { of your resident alien card. If } \\
\text { you do not have an alien } \\
\text { registration number or resident } \\
\text { alien card, explain." }\end{array}$ & $\begin{array}{l}\text { Application: Asks for the } \\
\text { applicant's social security } \\
\text { number but states that the } \\
\text { provision of the number is } \\
\text { voluntary. }\end{array}$ \\
\hline Kentucky & \multicolumn{2}{|c|}{$\begin{array}{l}\text { Full Disclosure: "The applicant must give full and complete } \\
\text { response to all inquiries on the application as well as furnish any } \\
\text { additional documents requested in relation to the application." } \\
\text { KY. SUP. CT. R. 2.018(2). } \\
\text { "The application is to be signed by the applicant and notarized. } \\
\text { All answers on the application form must be completely candid. } \\
\text { Lack of candor could result in possible denial of character and } \\
\text { fitness certification. An applicant is required to submit in writing } \\
\text { any circumstance or occurrence that may reflect on their } \\
\text { character or fitness." } \\
\text { KY. SUP. CT. R. 2.018(4). }\end{array}$} \\
\hline & State Bar Rule: N/A & State Bar Rule: N/A \\
\hline & $\begin{array}{l}\text { Application: Requires proof of } \\
\text { citizenship or proof of legal } \\
\text { residency in the U.S. }\end{array}$ & Application: N/A \\
\hline Louisiana & \multicolumn{2}{|c|}{$\begin{array}{l}\text { Full Disclosure: "Lack of candor during the application process } \\
\text { may be independent grounds for a finding of lack of good moral } \\
\text { character by the Committee and refusal to certify the applicant to } \\
\text { the Court for admission. Such lack of candor, if discovered after } \\
\text { admission, may serve as the basis for disciplinary action by the } \\
\text { Louisiana Attorney Disciplinary Board. Applicants shall provide } \\
\text { complete and candid responses to all inquiries, whether on the } \\
\text { Bar Examination Application, the NCBE's Request for the } \\
\text { Preparation of a Character Report or Supplemental Report, or as } \\
\text { part of any investigation, inquiry or proceeding." } \\
\text { LA. SuP. CT. R. XVII } § 4(G) \text {. } \\
\text { "Until admitted to the Bar, an applicant is under a continuing } \\
\text { obligation to keep his or her application current and must update } \\
\text { responses whenever there is an addition to or a change to } \\
\text { information previously provided to the Committee or to the }\end{array}$} \\
\hline
\end{tabular}




\begin{tabular}{|c|c|c|}
\hline \multirow[t]{3}{*}{$\begin{array}{l}\text { Louisiana } \\
\text { (continued) }\end{array}$} & \multicolumn{2}{|c|}{$\begin{array}{l}\text { NCBE. Those updates must be made in writing and must include } \\
\text { all relevant documentation." } \\
\text { LA. SUP. CT. R. XVII } \S 4(\mathrm{H}) \text {. }\end{array}$} \\
\hline & $\begin{array}{l}\text { State Bar Rule: "Every } \\
\text { applicant for admission to the } \\
\text { Bar of this state shall meet all of } \\
\text { the following requirements: } \\
\text { (B) Be a citizen of the United } \\
\text { States or an alien lawfully } \\
\text { admitted for permanent } \\
\text { residence, or an alien otherwise } \\
\text { authorized to work lawfully in } \\
\text { the United States." } \\
\text { LA. SUP. CT. R. XVII } \S 3 .\end{array}$ & State Bar Rule: N/A \\
\hline & Application: N/A & Application: N/A \\
\hline \multirow[t]{3}{*}{ Maine } & \multicolumn{2}{|l|}{ Full Disclosure: N/A } \\
\hline & State Bar Rule: N/A & $\begin{array}{l}\text { State Bar Rule: "The } \\
\text { application, on a form to be } \\
\text { provided by the Board in } \\
\text { accordance with subdivision (d) } \\
\text { of this rule, shall set forth the } \\
\text { name, date and place of birth, } \\
\text { social security number, } \\
\text { permanent residence, and } \\
\text { current address of the } \\
\text { applicant..." } \\
\text { ME. BAR ADMISSION R. 5(b). }\end{array}$ \\
\hline & $\begin{array}{l}\text { Application: Asks of what } \\
\text { country the applicant is a citizen } \\
\text { and, if it is not the U.S., asks } \\
\text { what the applicant's } \\
\text { immigration status is. }\end{array}$ & $\begin{array}{l}\text { Application: Asks for the } \\
\text { applicant's social security } \\
\text { number. }\end{array}$ \\
\hline Massachusetts & \multicolumn{2}{|c|}{$\begin{array}{l}\text { Full Disclosure: "Until the attorney oath has been administered, } \\
\text { candidates have a continuing duty to disclose promptly any } \\
\text { changes that occur with respect to information given in response } \\
\text { to questions in the application. A candidate's failure or refusal to } \\
\text { supply information deemed relevant by the Board or otherwise to } \\
\text { cooperate with the Board may be grounds for denial of a } \\
\text { recommendation for admission. Failure to respond in a timely } \\
\text { manner, without good cause, to inquiries by the Board or to make } \\
\text { a timely request for an extension of time to respond shall } \\
\text { result in a declaration that the application for admission of the } \\
\text { candidate has been abandoned." } \\
\text { MASS. R. BD. BAR EXAM'RS V.1.2. }\end{array}$} \\
\hline
\end{tabular}




\begin{tabular}{|c|c|c|}
\hline \multirow{2}{*}{$\begin{array}{l}\text { Massachusetts } \\
\text { (continued) }\end{array}$} & State Bar Rule: N/A & State Bar Rule: N/A \\
\hline & Application: N/A & $\begin{array}{l}\text { Application: Asks for the } \\
\text { applicant's social security } \\
\text { number. }\end{array}$ \\
\hline \multirow[t]{3}{*}{ New Mexico } & \multicolumn{2}{|l|}{ Full Disclosure: N/A } \\
\hline & $\begin{array}{l}\text { State Bar Rule: "Every applican } \\
\text { shall have the burden of } \\
\text { establishing to the satisfaction } \\
\text { of the board that the applicant } \\
\text { possesses all of the following } \\
\text { qualifications is [sic]: } \\
\text { 7. is a citizen or national of the } \\
\text { United States, an immigrant } \\
\text { alien lawfully admitted for } \\
\text { permanent residence in the } \\
\text { United States, or an alien } \\
\text { otherwise authorized to work } \\
\text { lawfully in the United States." } \\
\text { N.M. SuP. CT. R. 15-103(B). } \\
\text { "All applications shall be under } \\
\text { oath on forms provided by the } \\
\text { board, shall contain such } \\
\text { information relating to the } \\
\text { applicant's qualifications and } \\
\text { eligibility as may be required by } \\
\text { the board, and shall include } \\
\text { applicant's age, residence, } \\
\text { addresses for at least the five (5) } \\
\text { years immediately preceding } \\
\text { date of application, citizenship, } \\
\text { occupations, general and legal } \\
\text { background and information as } \\
\text { to the applicant's background } \\
\text { and moral character. The Court } \\
\text { may revoke the license of any } \\
\text { attorney at any time upon } \\
\text { satisfactory showing that the } \\
\text { same was obtained by false } \\
\text { representations, fraud or } \\
\text { deceit." } \\
\text { N.M. SuP. CT. R. 15-104(A). }\end{array}$ & State Bar Rule: N/A \\
\hline & Application: N/A & Application: N/A \\
\hline
\end{tabular}


[Ariz. St. L.J.

\begin{tabular}{|c|c|c|}
\hline \multirow[t]{3}{*}{ Texas } & \multicolumn{2}{|l|}{ Full Disclosure: N/A } \\
\hline & $\begin{array}{l}\text { State Bar Rule: "To be eligible } \\
\text { for admission or reinstatement } \\
\text { as a licensed attorney in Texas, } \\
\text { the Applicant shall: } \\
\text { (5) qualify under one of the } \\
\text { following categories: } \\
\text { (A) be a United States citizen; } \\
\text { (B) be a United States National; } \\
\text { (C) be an alien lawfully } \\
\text { admitted for permanent } \\
\text { residence; } \\
\text { (D) be an alien otherwise } \\
\text { authorized to work lawfully in } \\
\text { the United States" } \\
\text { R. GOVERNING ADMISSION TO } \\
\text { THE BAR OF TEX. 2(a). } \\
\text { "A person who has applied to } \\
\text { take the bar examination may } \\
\text { not be denied admission to the } \\
\text { bar examination based on the } \\
\text { applicant's lack of: } \\
\text { (1) permanent residency in the } \\
\text { United States; or } \\
\text { (2) United States citizenship." } \\
\text { TEX. Gov"T CoDE ANN. § } \\
\text { 82.0271. }\end{array}$ & State Bar Rule: N/A \\
\hline & $\begin{array}{l}\text { Application: Asks for the } \\
\text { applicant's proof of citizenship } \\
\text { or USCIS status. }\end{array}$ & Application: N/A \\
\hline
\end{tabular}




\title{
Appendix B: Sample Policy Statements from Universities
}

\author{
Catholic University of America ${ }^{322}$ Admission of Undocumented Students to \\ Academic Study:
}

\section{Introduction}

The Catholic University of America admits students of any race, color, national or ethnic origin, sex, age, disability, or immigration status to all the rights, privileges, programs and activities generally accorded or made available to students at the university. It does not discriminate against students or applicants for admission, or employees or applicants for employment based on the basis of race, color, national or ethnic origin, or on the basis of sex, age, disability, or immigration status, in the administration of its educational or admissions policies or in any aspect of its operations, unless required by law.

The university strives to comply with all aspects of federal and state laws governing the enrollment and employment of individuals, including foreign nationals. Since there are no laws at either the federal or the District level that bar the University from enrolling any sort of student, and in keeping with the social justice teachings of the Catholic Church, the University will not consider a student's immigration status in its decision to admit and enroll academically qualified students to its academic programs. The University will not, however, provide undocumented students with any form of financial assistance that requires the provision of services, as that would constitute unauthorized employment.

II. Definitions

A. Undocumented Students: foreign-born students who lack documentation to establish their immigration status in accordance with the Immigration and Nationality Act of the United States and its implementing regulations.

B. Immigration and Nationality Act of 1954: Primary U.S. law that governs the ability of foreign nationals to reside and engage in activities in the U.S.

III.

A. Admission of foreign-born students

Foreign-born applicants for admission to academic programs at CUA will be considered for admission in accordance with University's admissions policies that are applicable to all students. An individual's immigration status will not be factored into the decision for admission into a specific academic program. Immigration status will be considered in matters pertaining to 
employment and/or the award of any forms of financial assistance that require the provision of services.

This policy is consistent with existing immigration regulations and with the U.S. Conference of Catholic Bishop's general guidance on migration and the treatment of undocumented. Admitting qualified students into academic programs, allow them to gain leadership skills and knowledge that can be used to create a meaningful future anywhere in the world.

B. Eligibility for Financial Assistance for Undocumented students

Undocumented students are not eligible for federal sources of financial aid. The University does not offer scholarships specifically for international students. Individual students may be eligible to apply for loans and scholarships that do not require the provision of services, subject to the terms and conditions of the granting agency.

\section{University of Chicago $^{323}$ :}

To: The campus community

From: Kimberly Goff-Crews, Vice President for Campus Life and Dean of Students in the University

Re: Undocumented Students

Date: October 7, 2010

In response to concerns and questions raised by members of our community about the University's stance toward students and prospective students who are undocumented immigrants, the University has issued the following statement:

The University of Chicago has, from its inception, been a place where the best and brightest minds from around the world can gather to shape ideas, produce new knowledge, and contribute to the betterment of human life. Our community has been deliberately inclusive, because it is from the widest possible range of perspectives and viewpoints that the most innovative ideas can be proposed, tested, and debated. We are committed to assembling a community of talented individuals regardless of their backgrounds, financial circumstances, or national origins. This commitment is further discussed in President Zimmer's statement on diversity, posted at http://www.uchicago.edu/diversity/ zimmer.shtml.

In this context, the University of Chicago considers for admission students from around the world. All students who

323. E-mail from Kimberly Goff-Crews, Vice President for Campus Life and Dean of Students in the University of Chicago, to University of Chicago campus community (Oct. 7, 2010), available at http://csl.uchicago.edu/pdfs/UndocumentedStudentsPublicStatement10-710.pdf. 
apply, regardless of citizenship, are considered for admission to the University and for every type of private financial aid which the University offers. In accordance with the law, the University admits and enrolls undocumented students and uses private funds to provide financial aid to support their studies.

Vassar College ${ }^{324}$ :

Q: What is Vassar's policy when it comes to financial aid for undocumented students?

A: Vassar College will give admission applications submitted by undocumented students the same consideration given to any other applications it might receive. Undocumented students who are admitted to Vassar will be offered financial assistance based on demonstrated need following the same procedures Vassar uses to grant aid to accepted international students. 